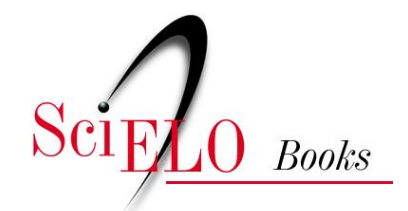

EDUFU

\title{
8 - Expressão do aspecto pelas perífrases verbais
}

\author{
Luiz Carlos Travaglia
}

\section{SciELO Books / SciELO Livros / SciELO Libros}

TRAVAGLIA, L.C. Expressão do aspecto pelas perífrases verbais. In: $O$ aspecto verbal no português: a categoria e sua expressão [online]. 5th ed. Uberlândia: EDUFU, 2016, pp. 181-252. ISBN: 978-655824-014-3. https://doi.org/10.7476/9786558240143.0010.

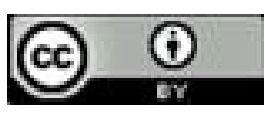

All the contents of this work, except where otherwise noted, is licensed under a Creative Commons Attribution 4.0 International license.

Todo o conteúdo deste trabalho, exceto quando houver ressalva, é publicado sob a licença Creative Commons Atribição $\underline{4.0}$.

Todo el contenido de esta obra, excepto donde se indique lo contrario, está bajo licencia de la licencia $\underline{\text { Creative Commons }}$ Reconocimento 4.0. 


\section{8 - Expressão do aspecto pelas perífrases verbais}

\section{1 - OBSERVAÇÕES GERAIS}

Inicialmente é preciso esclarecer que estaremos chamando de perífrase qualquer aglomerado verbal em que tenhamos um verbo (denominado auxiliar) ao lado de outro verbo em uma das formas nominais (denominado principal), e com uma função determinada de marcar uma categoria gramatical ou uma noção semântica qualquer. Não vamos discutir aqui o conceito de auxiliaridade. Primeiro porque foge a nossos objetivos e, segundo, porque se temos ou não auxiliares reais isso não afeta grandemente o problema da expressão do aspecto. Sobre a questão da auxiliaridade consultem-se os trabalhos de Lobato (1975) e Pontes (1973).

Algumas das funções que as perífrases podem ter são, por exemplo:

a. marcar o aspecto, como é o caso de ESTAR + GERÚNDIO ou CONTINUAR + GERÚNDIO. Exemplos:

675. Rogério estava almoçando, quando telefonei. (imperfectivo, cursivo, não acabado, durativo).

676. Todos continuarão escrevendo sobre o problema. (começado).

b. marcar a voz, como é o caso de SER + PARTICÍPIO, que indica voz passiva. Exemplo:

677. As meninas foram encontradas pelo policial.

c. marcar o tempo, como é o caso de IR + INFINITIVO que indica futuro. Exemplos: 
678. Vamos atravessar o rio a nado.

679. Os cavalos vão partir dentro de instantes.

d. marcar modalidade. Exemplos:

680. Tenho de limpar a casa hoje. (obrigação - TER + DE + INFINITIVO)

681. Quero ir ao parque. (volição - QUERER + INFINITIVO)

682. Devo ler este livro para fazer o trabalho. (necessidade - DEVER + INFINITIVO)

e. marcar determinadas noções semânticas, tal como a registrada nos exemplos abaixo.

683. Só sei que ele veio a comprar a fazenda do Sr. Miguel. (resultado final - VIR + A + INFINITIVO)

684. O rapaz acabou confessando sua culpa. (resultado final - ACABAR + GERÚNDIO)

Muitas vezes a perífrase marca duas coisas ao mesmo tempo. Veja-se os exemplos abaixo:

685. O carteiro tinha entregue o telegrama, quando cheguei. (TER + PARTICÍPIO. Aspecto: acabado; tempo: passado relativo, anterioridade).

686. A tinta vai esparramando sobre o papel. (IR + GERÚNDIO: noção semântica: progressão; aspecto: durativo)

687. O rapaz está para saltar sobre o animal. (Aspecto: não começado; tempo: futuro próximo).

Naturalmente, interessam-nos aqui, de forma mais direta as perífrases que marcam aspectos. Por vezes comentaremos perífrases não marcadoras desta categoria, apenas para deixar isto claro. Para facilidade de exposição, agrupamos as perífrases ou pelo auxiliar de que são formadas, ou pelo tipo de aspecto que expressam.

No estudo dos aspectos expressos pelas perífrases, utilizamos como principais verbos télicos e atélicos, verbos estáticos (de estado ou não), verbos de 
situações dinâmicas (processos e eventos) e verbos transformativos. ${ }^{1}$ Observar-se-á que, muitas vezes, o tipo de verbo principal altera o aspecto expresso pela perífrase.

\section{2 - AS PERÍFRASES DE TER E HAVER}

\subsection{1 - TER + PARTICÍPIO}

A perífrase TER + PARTICÍPIO expressa em todos os tempos e formas nominais, exceto no presente do indicativo, e com qualquer tipo de verbo principal os aspectos perfectivo e acabado. Exemplos:

688. Orlando tinha roncado à noite e ela estava nervosa por isso.

689. Muitas bombas terão explodido antes que prendam os guerrilheiros.

690. Eu teria emoldurado muitos quadros se a cola não tivesse acabado.

691. Embora Pedro tenha estado feliz durante o dia, à noite sentia-se deprimido.

692. Se esse menino tivesse engolido a bola de gude, teríamos de levá-lo ao médico.

693. Quando tiverem nascido muitos filhotes, começaremos a seleção.

694. José ter caminhado de manhã, deixou-o bem disposto.

695. Tendo chovido muito, as ruas estavam inundadas.

Essa perífrase não é usada nem no pretérito perfeito do indicativo, nem no pretérito mais-que-perfeito do indicativo, provavelmente porque estes dois tempos marcam o aspecto perfectivo e o segundo deles marca também o acabado e haveria então dois recursos, para expressão da mesma noção, o que iria contra o princípio de economia da língua. Said Ali (1971, p.162, § 826) registra que esta perífrase foi usada no pretérito perfeito do indicativo, mas que tal forma foi banida pelo uso como supérflua, uma vez que tinha o mesmo valor do pretérito perfeito do verbo principal. Dias (1970, p.191-192) registra alguns exemplos deste uso. Abaixo transcrevemos os dois exemplos apresentados por Said Ali.

696. "Depois que el Rei teve determinado de pelejar... mandou duas gallees." (Fernão Lopes - D. J. 26).

697. E como teve feito nella o que quiz, foi cercar D. João no forte em que esteve. (Couto - Déc. 4, 10,6).

\footnotetext{
${ }^{1}$ Chamamos de verbos transformativos aqueles que expressam uma mudança de estado ou de forma.
} 
Os dois autores afirmam que a perífrase, neste tempo, era usada para indicar que em um momento do passado a ação estava consumada.

No presente do indicativo, a perífrase em questão marca o imperfectivo, o não acabado e o iterativo. Por influência do tipo do verbo principal, podemos ter o durativo e o cursivo no lugar do iterativo. Vejamos alguns exemplos:

698. Nei Matogrosso tem cantado na televisão. (imperfectivo, iterativo, não acabado).

699. Meu irmão tem mandado notícias. (imperfectivo, iterativo, não acabado).

700. Tenho caminhado de manhã. (imperfectivo, iterativo, não acabado).

701. O rapaz tem partido pela manhã. (imperfectivo, iterativo, não acabado).

702. Tenho amado você desde que a conheci. (imperfectivo, cursivo,durativo, não acabado).

703. O paciente tem respirado bem. (imperfectivo, cursivo, durativo, não acabado).

704. Nos últimos anos Marta tem vivido modestamente. (imperfectivo, cursivo, durativo, não acabado).

O cursivo tende a ser expresso, quando os verbos indicam situações que não aceitam descontinuidade. É o caso dos verbos de sentimentos (exemplo 702) e de verbos como "respirar" ou "viver". (exemplos 703 e 704).

Com os verbos de estado, devido o seu valor durativo, a iteratividade se enfraquece e a forma é, muitas vezes, sentida como tendo aspectos durativo e cursivo. Exemplos:

705. Pedro tem estado contente. (imperfectivo e não acabado) (cursivo e durativo ou iterativo?)

706. Rafael tem andado preocupado com você. (imperfectivo e não acabado) (cursivo e durativo ou iterativo?)

707. Não se preocupe. Marieta tem sido feliz a seu modo. (imperfectivo, cursivo, durativo, não acabado)

708. Júlio tem sido muito gentil comigo. (imperfectivo e não acabado) (cursivo e durativo ou iterativo?)

709. a - Jorge tem ficado calado. (imperfectivo e não acabado) (cursivo e durativo ou iterativo?) 
b - Jorge tem ficado calado nas reuniões. (imperfectivo, iterativo, não acabado)

Nos casos em que há dúvida parece haver uma tendência maior para a interpretação durativa e cursiva. Entretanto, a opção entre cursivo e durativo por um lado e iterativo do outro depende muito do contexto em que o falante situa a frase. Assim, por exemplo, em (708), se o falante estiver considerando atos de gentileza, teremos o iterativo com toda certeza. Em (709-b) o iterativo é claramente definido em função do adjunto adverbial "nas reuniões".

Também com os verbos transformativos há o mesmo tipo de problema. Se o verbo transformativo expressa um evento, teremos imperfectivo não acabado e iterativo como no exemplo (710).

710. José tem adoecido, o que me impede de sair.

Mas se expressa um processo, podemos ter tanto uma interpretação iterativa como uma interpretação durativa e cursiva. Não parece haver qualquer sistematização possível, mas a interpretação durativa e cursiva aparece mais vezes, quando o verbo é intransitivo ou usado como tal. Exemplos:

711. José tem engordado muito. (imperfectivo, não acabado, durativo, cursivo)

712. As folhas do álbum têm amarelado de uns tempos para cá. (imperfectivo, não acabado, durativo, cursivo)

713. A fumaça tem empretejado as paredes. (imperfectivo, não acabado, durativo, cursivo)

714. a - José tem arredondado esta pedra. (imperfectivo, iterativo, não acabado).

b - José tem arrendondado estas pedras. (imperfectivo, não acabado, iterativo).

c - José tem arredondado pedras. (imperfectivo, não acabado, iterativo).

715. Precisamos mudar a fórmula, pois a massa tem endurecido muito rápido. (imperfectivo, não acabado, iterativo).

716. Carlos tem afinado muito a ponta dos espetos. (imperfectivo, iterativo, não acabado).

717. O antiquário tem amarelado folhas de papel para fazer imitações de originais antigos. (imperfectivo, não acabado, iterativo). 
Nestes casos, um adjunto adverbial pode marcar ou reforçar a iteratividade. Exemplos:

718. As folhas têm amarelado em agosto. (imperfectivo, habitual, não acabado).

719. José tem arredondado pedras toda manhã. (imperfectivo, iterativo, não acabado).

Como se pode observar, o fato de termos iterativo ou cursivo e durativo parece depender do significado próprio do verbo e do contexto.

Pode-se, então, dizer que a perífrase "ter + particípio", no presente do indicativo, expressa o imperfectivo, o não acabado e o iterativo, mas que, em certos casos, em função principalmente do significado do verbo, temos o durativo e o cursivo, e não o iterativo.

Devido a este valor iterativo, quando o verbo indica uma situação que não se repete para o mesmo ser, o sujeito (se o verbo for intransitivo) ou o objeto (se o verbo for transitivo) terão que ser plurais, conter a ideia de pluralidade ou poder ser tomados num sentido genérico. Em caso contrário teremos uma frase estranha ou inaceitável. Exemplos:

720. a - Tenho emoldurado muitos quadros. (imperfectivo, iterativo, não acabado).

b - (?) Tenho emoldurado um quadro.

O exemplo (720b) pode ter uma interpretação imperfectiva e iterativa, em que se estaria dizendo que a pessoa trabalha em diferentes períodos na emolduração do quadro. Entretanto (720b) não é a forma mais natural que um falante do Português usaria para expressar tal ideia. Provavelmente ele diria algo como: "Trabalho (ou tenho trabalhado) todos os dias na emolduração de um quadro". Outra interpretação de (720b) seria imperfectiva, durativa e cursiva, mas seria igualmente estranha por não ser a forma mais natural de expressar o pensamento em questão. $\mathrm{O}$ falante do Português preferiria dizer "Estou emoldurando um quadro" ou "Venho emoldurando um quadro".

721. a - Têm nascido muitos filhotes ultimamente. (imperfectivo, iterativo, não acabado).

b - * Tem nascido um filhote. 
722. a - Esse menino tem engolido coisas estranhas. (imperfectivo, iterativo, não acabado).

$\mathrm{b}-*$ Esse menino tem engolido uma bolinha de gude.

723. a - Muitas bombas têm explodido ultimamente. (imperfectivo, iterativo, não acabado).

b - * Uma bomba tem explodido ultimamente.

724. a - Têm morrido muitas rezes com a peste. (imperfectivo, iterativo, não acabado).

b - *Tem morrido uma rês com a peste.

De (721) a (724), as frases b são inaceitáveis, porque o verbo expressa um evento, o que impossibilita interpretações semelhantes às dadas a (720b).

Com processos atélicos e a colocação de um elemento adverbial que marca o momento de início do processo, a perífrase no presente do indicativo permite uma interpretação imperfectiva, durativa e cursiva, entretanto a frase, nestes casos, não é a mais natural para expressão do pensamento em causa e soará como estranha ou totalmente inaceitável. Exemplos:

725. a - ? José tem caminhado desde as cinco horas.

b - ? José tem cantado desde as vinte horas.

Para expressão das ideias contidas em (725a, b) com interpretação durativa e cursiva o falante do Português prefere frases como (726):

726. a - José está caminhando desde as cinco horas.

b - José está cantando desde as vinte horas.

Dias (1970, p.190) dá um exemplo em que a perífrase ter + particípio no presente do indicativo marcaria aspecto acabado e que transcrevemos abaixo (exemplo 727). ("Também serve de exprimir que no momento em que a pessoa falla, uma acção está consumada...”).

727. Tenho acabado, Fiéis, o meu discurso (VIEIRA, I, 950).

Esse tipo de construção não se usa mais e um exemplo como (727) tende a ser interpretado como tendo a perífrase sobre que falamos em 8.2.3. 
Câmara Júnior (1974a) diz que, em construções como (728), a perífrase marca o cursivo. Realmente isto acontece, mas o que temos aqui, na verdade, é uma construção com a perífrase de 8.2 .3 adiante.

728. "O nome que no peito escrito tinhas" (Lus. III - 120).

\subsection{2 - HAVER + PARTICÍPIO}

A perífrase HAVER + PARTICÍPIO tem o mesmo valor aspectual que a perífrase TER + PARTICÍPIO, valendo para aquela os comentários feitos para esta. Eis alguns exemplos em que podemos observar que haver + particípio marca os aspectos acabado e perfectivo:

729. Quando cheguei, Marina havia picado a carne.

730. Seu primo haverá chegado, quando voltarmos à fazenda.

731. Embora Joel haja falado comigo, não posso fazer nada.

732. Se ele houvesse emagrecido um pouco, a roupa the ficaria melhor.

733. Havendo trazido o livro, pediu-me que lesse para ele.

É importante observar que a perífrase haver + particípio não é usada no presente do indicativo e que as frases construídas com esta forma são inaceitáveis. Exemplos:

734. * Milton há cantado em muitas cidades do interior.

735. * Mamãe há preparado um frango delicioso.

736. * Os alunos hão falado que suas aulas são excelentes.

737. * Havemos recebido muitos convites.

\subsection{3 - TER + PARTICÍPIO VARIÁVEL}

A perífrase TER + PARTICÍPIO (variável) expressa os aspectos imperfectivo, cursivo, não acabado e durativo, para a situação referencial, que é um estado, e o acabado para a situação narrada de cujo término resultou o estado expresso. Isto com todos os tempos flexionais, exceto com os pretéritos perfeito e mais-que-perfeito do indicativo, em que temos o perfectivo, o acabado e o durativo para a situação referencial e o acabado para a situação narrada. Esta perífrase geralmente aparece em construções do tipo TER + OBJETO + PARTICÍPIO, onde o particípio tem a função de um predicativo do objeto com o qual concorda em gênero e número. 
Diante disso, podemos considerar o verbo ter, nestas construções, como um verbo relacional ${ }^{2}$ e o particípio como um adjetivo. Como se poderá ver, isto é inteiramente válido, pois, neste caso, o verbo ter se comporta exatamente como um verbo de estado no que se refere à expressão do aspecto.

Vejam-se os exemplos (72) e (73) que reescrevemos e (738) a (747) abaixo.

72 Tenho a lição estudada.

a) S.R.: ter estudada - imperfectivo, cursivo, não acabado, durativo.

b) S.N.: estudar a lição - acabado.

73 Bernarda (que vestiu um casaco e tem posta uma mantilha preta. A observar Amália com desconfiança): "Estás hoje muito janeleira, Amália!" - B. Santareno.44

a) S.R.: ter posta - imperfectivo, cursivo, não acabado, durativo.

b) S.N.: Pôr a mantilha - acabado.

738 O menino tinha o animal preso em casa.

a) - S.R.: ter preso - imperfectivo, cursivo, não acabado, durativo.

b) - S.N.: prender o animal - acabado.

739 Ele terá a massa preparada, quando for o momento de usá-la. a - S.R.: ter preparada - imperfectivo, cursivo, não acabado, durativo. b - S.N.: preparar a massa: acabado.

740 Eu teria a casa lavada, se a água não tivesse acabado. a - S.R.: ter lavada - imperfectivo, cursivo, não acabado, durativo. b - S.N.: lavar a casa - acabado.

741 É importante que você tenha os animais presos, quando chegarmos. a - S.R.: ter presos - imperfectivo, cursivo, não acabado, durativo. b - S.N.: prender os animais - acabado.

742 Embora Ademilde tivesse os retalhos cortados, não montou a colcha.

a - S.R.: ter cortados - imperfectivo, cursivo, não acabado, durativo. b - S.N.: cortar os retalhos - acabado.

743 Se você tiver a conferência preparada, poderá fazê-la hoje. a - S.R.: ter preparada - imperfectivo, cursivo, não acabado, durativo. b - S.N.: preparar a conferência - acabado.

\footnotetext{
${ }^{2}$ Ver o que diz Said AliI (1971, p.159, § § 811-812) sobre esta construção.
} 
744. Termos muitos quadros emoldurados é uma vantagem.

a - S.R.: ter emoldurados - imperfectivo, cursivo, não acabado,durativo.

b - S.N.: emoldurar os quadros - acabado.

745. Tendo a mesa posta quando chegarem, poderemos servir com maior presteza.

a - S.R.: ter posta - imperfectivo, cursivo, não acabado, durativo. b - S.N.: pôr a mesa - acabado.

746. Cecília teve os olhos postos em você durante muito tempo.

a - S.R.: ter postos - perfectivo, acabado, durativo.

b - S.N.: pôr os olhos em - acabado.

747. O soldado tivera a arma apontada para o presidente, mas desistiu de atirar.

a - S.R.: ter apontada - perfectivo, acabado, durativo.

b - S.N.: apontar a arma em - acabado.

Castilho (1967), que caracteriza o perfectivo como acabado, apresenta frases do tipo de (72) e (73) como tendo aspecto Perfectivo Resultativo em virtude do acabado da situação narrada. Esta não nos parece a melhor análise, já que não são considerados os aspectos presentes na situação referencial.

A construção correspondente a "ter + objeto + particípio variável" com o verbo haver, que para alguns teria o mesmo valor, não é usada hoje em dia, e as frases com ela formadas são sentidas como estranhas ou inaceitáveis pelos falantes.

É interessante observar que existem algumas restrições ao uso desta perífrase. ${ }^{3} \mathrm{Na}$ verdade, esta construção só é possível com verbos que se encaixem em um dos esquemas de (748). Nestes o termo "afetado" indica que o verbo deve expressar uma situação, de cuja conclusão resulte um estado novo e duradouro no objeto ou sujeito, conforme o caso.

748.

$$
\begin{aligned}
& \text { a - Sujeito agente }+ \text { verbo }+ \text { objeto afetado. } \\
& \text { b - Sujeito afetado }+ \text { verbo. }
\end{aligned}
$$

\footnotetext{
${ }^{3}$ Ao realizar o estudo da expressão do aspecto pelas perífrases encontramos uma série de restrições ao uso das mesmas com certos tipos de verbos, ou em certos contextos. Não vamos no corpo deste trabalho expôr estas restrições, porque estaríamos fugindo a nosso objetivo primeiro e para evitar constantes interrupções na exposição daquilo que, basicamente, constitui nosso estudo. As restrições ao uso de "ter + objetivo + particípio variável" que expomos ficam a título de exemplo.
} 
Eis alguns exemplos em que se pode observar a ação da restrição acima.

749. * Tenho o trem partido desde cedo.

750. * Maria tem um rapaz amado.

751. * Temos a peça achada para você.

Verbos como chegar, respirar, nascer, chover, etc. não aceitam a construção. Os verbos transformativos, embora indiquem situações de cuja conclusão resulte um estado novo em um ser, parecem não admitir a construção. Esta sempre soa como estranha, principalmente quando se tem um adjetivo de sentido exatamente igual ao do particípio. Veja exemplos (752) e (753) abaixo.

752. ? José tem as porcas engordadas.

753. ? Tenho as folhas amareladas.

Naturalmente, com interpretações um pouco diferentes, (752) e (753) são mais aceitáveis.

É interessante observar que as restrições de uso de "ter + objeto + particípio" são as mesmas de "estar + particípio".

\section{3 - As PERÍfRASES DE ESTAR}

Antes de mais nada é preciso observar que todas as perífrases de estar marcam exatamente os mesmos aspectos que o verbo estar (ver item 9.1). Isto equivale a dizer que as perífrases de estar marcam os aspectos imperfectivo, cursivo, não acabado e durativo em todos os tempos flexionais e formas nominais, exceto nos pretéritos perfeito e mais-que-perfeito do indicativo em que expressam os aspectos perfectivo, acabado e durativo. Estes aspectos dizem respeito sempre à situação referencial. Como veremos, a diferença entre estas perífrases está normalmente no aspecto que atribuem à situação narrada. Vejamos cada uma delas e suas particularidades.

$$
\text { 8.3.1 - ESTAR + POR/PARA/EM + INFINITIVO }
$$

Inicialmente temos as perífrases ESTAR + POR + INFINITIVO, ESTAR + PARA + INFINITIVO e ESTAR + EM + INFINITIVO que marcam o aspecto não começado para a situação narrada, representada pelo infinitivo. Nestas três perífrases os elementos "por + infinitivo", "para + infinitivo" e "em + infinitivo" valem por estados, sendo que o primeiro deles é o que mais facilmente se sente como tal. 
A perífrase ESTAR + POR + INFINITIVO pode ser observada em exemplos como (34), (132), que reescrevemos abaixo, e (754) a (764).

34. Esta gaveta está por arrumar, mas só o farei quando tiver tempo.

132. A cozinha está por limpar.

754. Os quadros estavam por emoldurar, quando chegamos lá.

755. Se você continuar nesta moleza, as batatas estarão por fritar quando o pessoal chegar.

756. A escravidão estaria por abolir, se não tivesse havido os que lutaram pela abolição.

757. Embora a ponte ainda esteja por explodir, o inimigo não conseguirá atravessar o rio.

758. Embora a música estivesse por gravar, ela não compareceu ao estúdio.

759. Se os folhetos ainda estiverem por distribuir, você será despedido.

760. O livro estar por encadernar até hoje mostra o quanto você é relapso.

761. As paredes estando por pintar, quero que você escolha as cores.

762. O ginásio esteve por construir todo esse tempo, mas hoje é uma realidade.

763. Esta casa esteve por limpar até hoje.

764. Este artigo estivera por escrever mais de um mês, mas agora pude fazê-lo graças a sua ajuda.

Nas frases (34), (132) e (754) a (761) a situação referencial, que é um estado, tem os aspectos imperfectivo, cursivo, não acabado e durativo e a situação narrada tem aspecto não começado. Nas frases (762) a (764), a situação referencial tem aspectos perfectivo, acabado e durativo e a situação narrada tem aspecto não começado.

"Por + infinitivo" representa o estado do ser designado pelo sujeito, antes da realização da situação narrada.

Só admitem esta construção os verbos que se encaixem no esquema de (748 a). Aqui o sujeito é sempre o objeto afetado, o que gera uma certa passividade na significação das frases com "estar + por + infinitivo". Se o verbo, no sentido considerado, não admite a construção, e o sujeito é potente, a frase é interpretada pelo falante com um sentido semelhante ao de "estar + para + infinitivo". Veja exemplos (765) e (766). 
765. O trem está por partir. (= está para partir).

766. O avião está por chegar. (= está para chegar).

Frases como estas, embora possíveis com semelhante interpretação, não são usadas e são vistas como pouco naturais pelos falantes. Estes preferem marcar a iminência de ação com a perífrase "estar + para + infinitivo".

As frases formadas com verbos que geralmente só se encaixam no esquema (748 b) são estranhas ou ruins. Veja exemplo (767).

767. * José está por adoecer.

Se o verbo se encaixa tanto no esquema de (748a), quanto no de (748b), a frase será ruim no sentido que se encaixa em (748b) e boa no sentido que se encaixa em (748a). Exemplos:

768. a - A barreira está por arrebentar. (Alguém está encarregado de arrebentar a barreira) b - *A barreira está por arrebentar. (A barreira vai arrebentar).

769. a-As porcas estão por engordar. (Alguém vai engordar as porcas. Engordar $=$ cevar). b - *As porcas estão por engordar. (Engordar = ficar gordo).

A perífrase ESTAR + PARA + INFINITIVO se distingue de "estar + por + infinitivo", por marcar a noção temporal de futuro próximo, que se traduz na iminência de ação, além de marcar as noções aspectuais que já especificamos. Vejamos os exemplos (7 c), (35), (36) e (770) a (777) abaixo.

7c. Sua encomenda está para chegar.

35. Pedro está para emoldurar o quadro.

36. Seu irmão está para chegar.

770. Estava para chover e ela ficou preocupada, pois a filha estava na rua.

771. A bomba estará para explodir, quando a encontrarem.

772. Embora o trem esteja para partir vocês ainda poderão tomá-lo.

773. Embora os filhotes estivessem para nascer, todos estavam calmos na fazenda.

774. Você estar para caminhar de novo deixa todos felizes. 
775. Estando para mudar, não quis pintar a casa de novo.

776. Seu tio esteve para morrer, mas este médico conseguiu salvá-lo.

777. Ivan estivera para confessar a verdade ao irmão, mas achou melhor calar-se.

Nas frases (7c), (35), (36) e (770) a (775), a situação referencial tem os aspectos imperfectivo, cursivo, não acabado, durativo e a situação narrada o não começado. Nas frases (776) e (777), a situação referencial tem aspectos perfectivo, acabado e durativo e a situação narrada o não começado.

Como já dissemos, "para + infinitivo" tem um valor de estado que se torna mais claro, quando o verbo estar tem sentido de "ter disposição ou intenção" (exemplos 778 a 780). Neste caso a ideia de iminência de ação desaparece.

778. Não estou para ouvir tolices.

779. Naquele tempo eu não estava para amar alguém.

780. Ela me disse que não está para continuar fechada em casa.

O aspecto aqui é o mesmo de (7 c), (35), (36) e (770) a (775).

Quando a perífrase "estar + para + infinitivo" marca iminência de ação a noção aspectual aparece um pouco enfraquecida.

A perífrase de ESTAR + EM + INFINITIVO que, segundo Dias (1970, p.232), tem o mesmo valor de "estar + por + infinitivo", no que respeita a indicar algo ainda não realizado, tem o mesmo valor aspectual desta, como já vimos, mas difere por trazer em si a ideia de "ter disposição ou intenção". Vejamos alguns exemplos:

781. "Estamos em partir amanhã". (T. Silva Brandão).

782. "Estou em dizer que toda matungama / não vale a poeira que bulir na estrada" (Vargas Neto - Tropilha, Crioula e Gado Xucro). ${ }^{4}$

783. Meu irmão esteve em pedir-lhe o terno emprestado, mas ficou com vergonha de fazê-lo.

Em (781) e (782) a situação referencial tem os aspectos imperfectivo, cursivo, não acabado e durativo, enquanto em (783) tem o perfectivo, o acabado e o durativo. Nas três frases a situação narrada tem o aspecto não começado.

\footnotetext{
${ }^{4}$ Exemplo (781) apud Fernandes (1965, p.324), verbete “estar". (FERNANDES, F. Dicionário de verbos e regimes. Porto Alegre: Globo, 1965.). Exemplo (782) apud Ferreira (1975, p.578), verbete "estar". (FERREIRA, A. B. de H. Novo dicionário da língua portuguesa. Rio de Janeiro: Nova Fronteira, 1975. 1499p.)
} 
A perífrase "estar + em + infinitivo" praticamente não é usada hoje em dia e "estar + para + infinitivo" vem tomando seu lugar (ver exemplos 778 a 780).

\subsection{2 - ESTAR + GERÚNDIO}

A perífrase ESTAR + GERÚNDIO não traz a questão da distinção entre situação narrada e referencial. Temos apenas uma situação que, com todas as flexões verbais, exceto os pretéritos perfeito e mais-que-perfeito do indicativo, apresenta os aspectos imperfectivo, cursivo, não acabado e durativo como se pode observar nos exemplos (784) a (793).

784. As folhas da avenca estão amarelando.

785. O bebê estava nascendo, quando me avisaram.

786. Quando você for procurar Maria, ela já estará amando outro.

787. Hilário estaria pesquisando este assunto, se você não o tivesse desanimado.

788. Embora Neilton esteja folheando o livro, não o está lendo.

789. Embora estivesse ventando muito, Aníbal saiu com o barco.

790. Se a água estiver fervendo, desligue o fogo para mim.

791. Quando José estiver adoecendo, virá nos pedir socorro.

792. O paciente estar respirando bem é um bom sintoma.

793. Estou emoldurando vários quadros para ele.

Muitas vezes, por influência do adjunto adverbial, temos uma interpretação iterativa. Nestes casos, o adjunto adverbial marca o iterativo ou o habitual, contrariando a tendência aspectual da perífrase. Exemplos:

794. O trem está partindo pela manhã. (imperfectivo, não acabado, iterativo).

795. a - O rapaz estava chegando às oito horas.

b - Todos os dias o rapaz estava chegando às oito horas.

A frase (795a) é ambígua, podendo ser iterativa ou não, já (795b) só pode ser iterativa.

796. Hoje em dia os bebês estão nascendo mais fortes (imperfectivo, não acabado, habitual).

797. José está caminhando de manhã (ou toda manhã). (imperfectivo, não acabado, iterativo). 
Com o auxiliar nos pretéritos perfeito e mais-que-perfeito do indicativo, os aspectos marcados serão o perfectivo, o acabado e o durativo como se pode observar nos exemplos (798) a (802).

798. Esse menino esteve comendo doces a tarde toda.

799. Mamãe esteve caminhando pelo bosque hoje de manhã.

800. Seu filho esteve cantando para nós, mas já se foi.

801. Estivera chovendo de manhã e todos ficaram em casa.

802. Pedro estivera olhando algumas camisas, mas não gostou de nenhuma.

Com a perífrase nestes dois pretéritos, temos um valor cessativo que torna estranhas ou ruins frases com verbos de evento (exemplos: 803 e 804); com verbos de processo que não aceitam descontinuidade, como amar e respirar (exemplo: 805); com verbos de estado que por si já marcam o acabado, quando nos pretéritos perfeito ou mais-que-perfeito do indicativo (exemplo 806); com certos verbos transformativos, não agentivos (exemplos: 807 e 808).

803. * O bebê esteve nascendo.

804. * O rapaz esteve chegando em casa.

805. ? Maria esteve amando João.

806. ?* Antônio esteve sendo feliz.

807. ?* José esteve adoecendo.

808. ?* Sebastião esteve engordando muito.

As frases com verbos de evento parecem se tornar mais aceitáveis, quando uma interpretação iterativa é possível, seja por influência de um adjunto adverbial seja porque temos um sujeito plural, se o verbo é intransitivo, ou um objeto plural se o verbo é transitivo. Exemplos:

809. a - Os trens estiveram partindo pela manhã. (perfectivo, acabado, iterativo).

b - O trem esteve partindo pela manhã. (perfectivo, acabado, iterativo).

810. Os filhotes estiveram nascendo fracos, mas agora está tudo bem. (perfectivo, acabado, iterativo).

811. Os homens estiveram explodindo bombas a noite toda. (perfectivo, acabado, iterativo). 
812. $\mathrm{O}$ rapaz esteve chegando em casa às oito horas todos os dias (perfectivo, acabado, iterativo).

Como se pode observar, mesmo sendo possíveis, estas frases soam como pouco naturais e (812) é bastante estranha. Na verdade, os pensamentos registrados em (809) a (812) são mais naturalmente expressos, quando se usa a perífrase "andar + gerúndio".

A perífrase ESTAR + A + INFINITIVO, que é pouco usada no Brasil, tem o mesmo valor aspectual que a perífrase "estar + gerúndio", sendo válidos para aquela os comentários feitos para essa. Quanto à exemplificação, é suficiente mudar nas frases (784) a (812) o "gerúndio" por “a + infinitivo". Cumpre apenas anotar que estar $+\mathrm{a}+$ infinitivo é possível com o auxiliar no gerúndio, o que não ocorre com sua equivalente. Veja exemplos (813) a (816) em que temos sempre os aspectos imperfectivo, cursivo, não acabado e durativo.

813. Estando o ônibus a partir não pudemos tomá-lo.

814. Estando a caminhar desde cedo, ao meio dia Edgar sentiu-se cansado.

815. Estando a cantar, mamãe não me ouviu chegar.

816. Estando a chegar naquele instante, o rapaz não sabia de nada.

\subsection{3 - ESTAR + PARTICÍPIO}

A perífrase ESTAR + PARTICÍPIO se diferencia aspectualmente das demais perífrases de estar, por apresentar a situação narrada como acabada. O particípio representa sempre um estado e funciona como nome predicativo. Exemplos:

817. O assaltante está preso.

818. A porta estava arrebentada.

819. O poço estará furado, quando vocês mudarem para cá.

820. Antônio estaria morto, se não o tivessem tirado da água.

821. Embora os rapazes estejam irritados, falarei com eles agora.

822. Se a carne estivesse picada, eu poderia prepará-la para você.

823. Se o livro estiver lido, podemos fazer o debate hoje.

824. A porta estar aberta me pareceu estranho.

825. Os folhetos estando distribuídos podemos começar o trabalho.

826. Meu cachorro esteve acorrentado durante três dias.

827. Essa casa já esteve limpa hoje.

828. Meu primo estivera sumido por duas semanas, sem dar notícia. 
Nas frases (817) a (825) temos os aspectos imperfectivo, cursivo, não acabado e durativo para a situação referencial, que nas frases (826) a (828) tem os aspectos perfectivo, acabado e durativo. A situação narrada em todas estas frases tem aspecto acabado.

Devido ao valor cessativo da perífrase nos pretéritos perfeito e mais-que-perfeito do indicativo, se o particípio indicar um estado que não pode cessar teremos uma frase ruim, inaceitável com estas formas. Veja exemplos (829) a (833).

829. * O filhote esteve nascido.

830. ?* O livro esteve lido durante um mês.

831. * A música esteve cantada.

832. * Os vinte quilômetros estiveram percorridos.

833. ?* A carne esteve cozida.

Uma outra particularidade desta perífrase no pretérito perfeito do indicativo, é que parece termos a possibilidade de ter frases que não têm aspecto acabado para a situação referencial como é o caso de (834) abaixo.

834. A porta esteve arrebentada todo esse tempo e só agora é que você notou?

Em (834) teríamos aspectos perfectivo, não acabado e durativo para a situação referencial, e acabado para a situação narrada (arrebentar). O não acabado, aqui, parece se dever ao fato de que o pretérito perfeito do indicativo estaria sendo usado pelo pretérito imperfeito do indicativo, o que equivale a dizer que (834) deveria ter a forma de (835).

835. A porta estava arrebentada todo esse tempo e só agora é que você notou?

Não encontramos nenhum outro exemplo semelhante a (834).

Para a perífrase "estar + particípio" valem as mesmas restrições de uso que colocamos para a perífrase "ter + objeto + particípio variável”.

Castilho (1967), considerando o acabado da situação narrada, apresenta frases do tipo de (817), com o verbo no presente do indicativo, como tendo aspecto Perfectivo Resultativo, já que para ele o Perfectivo = acabado. Não concordamos com esta análise, pois ela não considera o estado, que é a situação referencial, e que, claramente, não é acabada. 
Como se pode observar, as perífrases de estar formam um sistema completo, para a indicação das fases de realização da situação expressa pelo principal que, em dois casos, representa a situação narrada:

$$
\begin{array}{lll}
\text { não começado } \rightarrow & \text { estar + por } & + \text { infinitivo } \\
& \text { estar }+ \text { para } & + \text { infinitivo } \\
& \text { estar }+ \text { em } & + \text { infinitivo }
\end{array}
$$

Começado ou não acabado $\quad \rightarrow \quad$ estar + gerúndio

Acabado $\rightarrow$ estar + particípio

\section{4 - As PERÍFRASES DE IR}

\subsection{1 - IR + INFINITIVO}

A perífrase IR + INFINITIVO marca tempo futuro com todas as flexões temporais com que é possível. Vejamos alguns exemplos:

836. A execução vai sair às oito horas.

837. Ia chover por isso resolvi não sair.

838. Mesmo que a bomba vá explodir daqui a duas horas, é bom todos abandonarem a área imediatamente.

839. Se eu fosse convidar alguém, você seria o primeiro.

840. Quando eu for copiar o texto, faço as correções necessárias.

É comum, dependendo do significado do verbo principal ou do tempo em que está o verbo ir, termos não uma perífrase marcadora de futuridade, mas sim o verbo "ir", indicando locomoção para um lugar onde se realiza o indicado pelo verbo no infinitivo. Nos pretéritos perfeito e mais-que-perfeito do indicativo, isto ocorre sistematicamente (exemplos 842 a 845). Com estes dois tempos a perífrase só existe em orações temporais com a conjunção "quando" (exemplos 846 e 847). Com o pretérito mais-que-perfeito estas frases com a perífrase "ir + infinitivo" são estranhas ou ruins (exemplos 848 e 849).

841. Todo dia ia regar a horta para mim.

842. Maria foi tomar conta do bebê de Marina.

843. As meninas foram apanhar jabuticaba.

844. Quando cheguei à fazenda, José fora preparar canteiros para ajudar seu pai. 
845. Ontem fomos visitar meus tios.

846. Quando o filhote foi nascer, todos vieram ver.

847. Quando Madalena foi abrir a caixa, sua mãe a chamou.

848. ?* Quando eu fora pegar o livro, ele disse que não podia emprestá-lo.

849. * Quando eu fora escrever para você, me disseram que você havia mudado e não tínhamos seu novo endereço.

Nestas frases em que ir + infinitivo deixa de marcar tempo futuro, temos a expressão de aspectos devida à flexão temporal e a outros meios, como o adjunto adverbial. Assim, por exemplo, em (841), temos aspectos imperfectivo, não acabado e habitual devidos ao pretérito imperfeito do indicativo e à influência do adjunto adverbial "todo dia"; em (842), temos aspecto perfectivo devido ao pretérito perfeito do indicativo

Marcando o tempo futuro e impedindo a expressão do aspecto, esta perífrase parece anular qualquer diferença de significado entre frases como (850) e (851), em que a única diferença seria aspectual.

850. Quando eu ia falar ele chegou.

851. Quando eu fui falar ele chegou.

\subsection{2 - IR + GERÚNDIO}

A perífrase IR + GERÚNDIO marca o aspecto durativo com qualquer flexão verbal. Ela apresenta a situação como tendo desenvolvimento gradual, isto é, marca a ideia de progressividade. As demais noções aspectuais presentes nas frases com esta perífrase vão depender de outros fatores, tal como a flexão temporal. Vejamos alguns exemplos:

852. Os anos vão passando e não consigo encontrar um amor. (imperfectivo, cursivo, não acabado, durativo).

853. Vai chegando o momento em que todos saberão da verdade. (imperfectivo, cursivo, não acabado, durativo).

854. Pedro ia caminhando pelas ruas, enquanto pensava em seu problema. (imperfectivo, cursivo, não acabado, durativo).

855. João foi construindo a casa nas suas folgas. (perfectivo, durativo).

856. Lívio fora esquecendo os parentes, para não sofrer mais. (perfectivo, durativo).

857. Você irá catando o feijão para mim. (durativo). 
858. Se eu não pusesse esse adubo as folhas iriam amarelando e secariam.(durativo).

859. Embora vá engordando a olhos vistos, Pedro não quer fazer regime. (imperfectivo, cursivo, não acabado, durativo).

860. Mesmo que José fosse preparando a carne, o churrasco sairia atrasado. (durativo).

861. Se você for lendo durante a viagem, não aproveitará nada da paisagem. (durativo).

862. Foi muito bom ir comprando o material com antecedência. (durativo).

É frequente termos um habitual no lugar do durativo, normalmente por influência de elementos adverbiais (adjunto ou oração), como nos exemplos (863) e (864). Nestes casos, cada realização da situação habitual indicada pela perífrase é durativa.

863. Quando ele vem aqui, vai chegando perto dela até ficar juntinho. (imperfectivo, não acabado, habitual).

864. Ele sempre ia rodando até ficar tonto. (imperfectivo, não acabado, habitual).

No pretérito imperfeito do indicativo, esta perífrase pode ser usada para indicar que a situação esteve prestes a realizar-se, como podemos observar nos exemplos (865) a (867) abaixo. Neste caso, a perífrase fica com o mesmo valor futuro de IR + INFINITIVO (Cf. com o exemplo 850).

865. Eu ia contando a Pedro sobre a festa, quando mamãe fez um sinal para que eu me calasse.

866. André ia comprando o carro, mas Antônio lhe disse que ele tinha problemas no motor.

867. Quando ele ia cantando a música, as luzes se apagaram.

Com verbos de movimento, a frase com esta perífrase é ambígua. Numa interpretação temos a perífrase com seu valor durativo, principalmente se a frase pode ser usada numa descrição simultânea. Noutra interpretação a perífrase se desfaz: o verbo ir passa a indicar locomoção e o verbo no gerúndio, a forma de locomoção. Veja exemplos (868) e (869). Com a segunda interpretação o aspecto 
será o indicado pela flexão temporal: imperfectivo, habitual, não acabado para (868) e perfectivo para (869).

868. Antônio vai caminhando para a igreja.

869. Ele foi correndo para casa.

\section{5 - As PERÍFRASES DE VIR}

\subsection{1 - VIR + INFINITIVO}

A perífrase VIR + INFINITIVO não marca aspecto. Esta perífrase indica tempo futuro ${ }^{5}$, caso em que não haverá qualquer aspecto expresso. Nas frases em que há aspecto, este depende de fatores como a flexão temporal e/ou elementos adverbiais (orações ou adjuntos). Nestes casos a ideia de futuro desaparece. Exemplos:

870. José vem conversar com você sobre isto. (futuro).

871. José vem conversar comigo todos os dias (imperfectivo, não acabado, habitual) - Aspectos presentes pela influência do adjunto adverbial "todos os dias".

872. Rafael vinha morar conosco, mas desistiu. (futuro).

873. Os elefantes vinham morrer aqui, por isso há tantas ossadas. (imperfectivo, acabado, habitual) - Aspectos devidos à flexão temporal.

874. O rapaz veio buscar o livro. (perfectivo, acabado) - Aspectos devidos à flexão temporal.

875. Embora minha irmã venha cuidar das crianças quando preciso, não gosta muito de fazê-lo. (imperfectivo, não acabado, habitual) - Aspectos devidos à influência da oração subordinada adverbial temporal "quando preciso".

\subsection{2 - VIR + A + INFINITIVO}

A perífrase VIR + A + INFINITIVO também marca futuro, mas difere de "Vir + Infinitivo", porque indica um ponto terminal, representado pela realização da situação expressa pelo verbo no infinitivo. Este ponto terminal é visto como um resultado, uma consequência de outros fatores.

\footnotetext{
${ }^{5}$ Pontes (1973) também afirma que essa perífrase marca futuro. (PONTES, E. Verbos auxiliares em português. Petrópolis: Vozes, 1973. 145 p.).
} 
876. Se o rapaz vem a partir por causa do mal tratamento que vocês lhe dão, vocês ficarão em dificuldade.

877. É possível que algum dia venhamos a conversar com você.

878. Se ele viesse a morrer eu não me perdoaria nunca.

Naturalmente, esta perífrase não marca aspecto e, quando há aspecto na frase com ela formada, este se deve normalmente a fatores como a flexão temporal e/ou a influência de elementos adverbiais (adjuntos ou orações). Exemplos:

879. Roberto tanto procurou que veio a encontrar o que queria. (perfectivo, acabado) - Aspecto devido à flexão temporal.

880. As crianças insistiam, porque Mariana sempre vinha a atendê-las em seus desejos. (imperfectivo, habitual). - Aspecto devido à influência do Adjunto adverbial "sempre".

\subsection{3 - VIR + DE + INFINITIVO}

A perífrase VIR + DE + INFINITIVO marca o aspecto acabado para a situação expressa pelo verbo no infinitivo, com qualquer flexão temporal em que seja possível. Esta perífrase marca também passado recente e é muito pouco usada, pois os falantes preferem utilizar a perífrase ACABAR + DE + INFINITIVO que expressa as mesmas noções. ${ }^{6}$

É desnecessário dizer que muitas gramáticas condenam, como galicismo, o uso de VIR + DE + INFINITIVO.

Em muitos tempos flexionais as frases são estranhas ou inaceitáveis. Exemplos:

881. Venho de assistir a missa e não quero discutir com você.

882. Estou desesperado, pois venho de perder todos os meus documentos.

883. Mariana vinha de caminhar pelo bosque.

884. Se o menino viesse de engolir um alfinete estariam todos apavorados.

885. Embora ele venha de pintar a casa, não está sujo de tinta.

886. Vindo de colher os frutos, o sr. Jerônimo pediu seu pagamento.

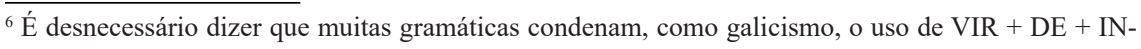
FINITIVO. 


\subsection{4 - VIR + GERÚNDIO}

A perífrase VIR + GERÚNDIO marca os aspectos imperfectivo, cursivo, não acabado e durativo com todas as flexões temporais em que é possível, exceto com os pretéritos perfeito e mais-que-perfeito do indicativo em que os aspectos marcados são o perfectivo e o durativo. Veja os exemplos (887) a (897) abaixo.

887. Os rapazes vêm trabalhando sem muitas condições.

888. Maria vinha amando Aldo em silêncio, mas resolveu abrir o jogo.

889. Você viria duvidando de nós até hoje, se Carlos não tivesse contado a verdade.

890. Embora Sérgio venha construindo sua casa devagar ainda não interrompeu os trabalhos nem uma vez.

891. Se você viesse arquivando os papéis direito, não teríamos todo esse trabalho agora.

892. É possível que seu irmão venha ocultando alguma coisa de vocês.

893. Qual a razão de você vir guardando todos estes bilhetes?

894. Bernardo veio sendo feliz com a esposa, até começar a ter ciúmes.

895. César, viemos poupando você enquanto pudemos, mas agora temos de lhe dizer tudo.

896. O filhote viera nascendo com dificuldade, mas no final todos se alegraram, porque era um belo filhote.

897. Celene viera odiando o tio, até descobrir a realidade dos fatos.

Nos pretéritos perfeito e mais-que-perfeito do indicativo, temos aspecto acabado se algo assinala que a situação foi concluída (ver exemplos 894 e 897).

Devido ao sentido temporal da perífrase, que expressa um prolongamento da situação desde um ponto qualquer do passado até o presente (momento em que se fala) ou até um momento indicado do passado, não encontramos exemplos em que a perífrase fosse usada com os futuros do presente e do subjuntivo. Quando a perífrase é usada nestes tempos, perde em parte o valor aspectual acima especificado e indica iminência de ação (exemplo 898), o que não ocorre com frequência; ou a perífrase se desfaz e temos o verbo "vir" indicando movimento, e o verbo no gerúndio indicando o que se realiza ao mesmo tempo em que se vem. (exemplos 899 a 901).

898. Quando ele vier chegando em silêncio para nos surpreender, dar-lhe-emos o maior susto. 
899. João virá admirando a paisagem de lá até aqui.

900. Tenho certeza que você virá chateando mamãe durante a viagem.

901. Se ele vier catando frutinhas pelo mato, demorará mais de uma hora para chegar.

Observe-se que, em (898) a (901), o aspecto durativo está presente.

A interpretação que especificamos acima para as frases (899) a (901), aparece também com a perífrase nos pretéritos perfeito e mais-que-perfeito do indicativo, caso em que é comum as frases serem ambíguas. Exemplos:

902. Este menino veio fazendo perguntas durante toda a viagem.

903. Marina estava nervosa porque Cláudio viera catando tampinhas pela rua.

Se o verbo principal é de movimento, indica o modo de locomoção e não o que se faz concomitantemente à locomoção expressa pelo verbo vir. Com tais verbos as frases são ambíguas em todos os tempos, podendo ter a interpretação de locomoção + modo de locomoção ou uma interpretação com o valor aspectual da perífrase especificado no início deste item. ${ }^{7}$ Exemplo:

904. O guarda vem caminhando para cá.

Às vezes o todo da frase favorece uma ou outra interpretação. Exemplos:

905. Vim correndo para cá assim que recebi o recado. (A interpretação favorecida é a de locomoção + modo de locomoção).

906. O Juninho vem engatinhando há vários dias. (A interpretação favorecida é a imperfectiva, cursiva, durativa, não acabada).

Se o verbo principal é de evento, a frase só será aceitável com o valor aspectual cursivo e durativo, se puder ser usada numa descrição simultânea. (exemplos 907 e 908).

907. Ele vem chegando de mansinho para nos assustar.

908. Esta planta vinha morrendo por falta de rega.

$\overline{{ }^{7} \text { Ambiguidade semelhante }}$ foi observada para a perífrase ir + gerúndio (cf. item 8.4.2). 
Se o uso em descrição simultânea não for possível, a perífrase vir + gerúndio de verbo de evento formará frases que só serão aceitáveis se interpretadas como iterativas (exemplos 909 a 911). Em virtude disso, se o verbo de evento expressa situação que só se realiza uma vez para cada ser, a frase só será boa se o sujeito (quando o verbo é intransitivo) ou o objeto (quando o verbo é transitivo) for plural para possibilitar o valor iterativo (exemplos 912 a 915). Algumas vezes o sentido iterativo é reforçado ou marcado por um adjunto adverbial (exemplos 916 e 917).

909. Rafael vinha faltando ao trabalho sem explicar porque. (imperfectivo, não acabado, iterativo).

910. O rapaz vem partindo da Estação da Luz. (imperfectivo, não acabado, iterativo).

911. Seu filho vem pulando o muro ao invés de entrar pelo portão. (imperfectivo, não acabado, iterativo).

912. a - * O filhote vem nascendo sadio. b - Os filhotes vêm nascendo sadios. (imperfectivo, não acabado, iterativo).

913. a - * A bomba vem explodindo há três dias.

b - As bombas vêm explodindo há três dias. (imperfectivo, não acabado, iterativo).

914. ? Josafá vem achando o livro. (Esta frase só é aceitável se imaginarmos que o livro é encontrado e perdido seguidamente).

915. a - * Este menino vem engolindo a bolinha de gude. (Esta frase só é admissível se imaginarmos uma situação em que a pessoa engole e expele a mesma coisa repetidas vezes).

b - Este menino vem engolindo bolinhas de gude. (imperfectivo, não acabado, iterativo).

916. O trem vem partindo às 5 horas. (imperfectivo, não acabado, iterativo).

917. Embora o Sr. José venha acordando às cinco horas todos os dias, só se levanta às sete. (imperfectivo, não acabado, iterativo).

\section{6 - AS PERÍFRASES ITERATIVAS E HABITUAIS}

\subsection{1 - ANDAR + GERÚNDIO}

A perífrase ANDAR + GERÚNDIO marca o aspecto iterativo com todas as flexões verbais em que é possível. Normalmente temos também o imperfectivo e o não acabado, exceto nos pretéritos perfeito e mais-que-perfeito do indicativo em que temos o perfectivo. Exemplos: 
918. Celina anda perguntando por você.

919. Os aviões andavam decolando sem permissão.

920. Se não fosse a vigilância constante, eles andariam roubando peças.

921. Mesmo que os rapazes andem acampando lá no vale, não vejo motivo para preocupação.

922. Se andássemos dançando tanto como o senhor diz, estaríamos mortos.

923. As sementes andarem brotando mais depressa é prova de que minha teoria está certa.

924. Se você andar comprando tolices, corto sua mesada.

925. Onofre andou perguntando por você.

926. Reginaldo andara testando um aparelho, sem permitir que alguém assistisse à experiência.

Com a perífrase no futuro do presente a maioria das frases é estranha ou ruim. Exemplos:

927. * O trem andará partindo atrasado, quando formos fazer a verificação.

928. * Andará chovendo no Rio, quando chegarmos lá.

Os falantes preferem usar a perífrase "estar + gerúndio" para expressar tais pensamentos. Entretanto é interessante observar que, se a frase com o verbo no futuro do presente for interrogativa, teremos um valor de presente hipotético, e a frase será perfeitamente aceitável e boa com os aspectos imperfectivo, não acabado e iterativo. Veja exemplos (929) a (931).

929. O trem andará partindo atrasado?

930. Andará chovendo no Rio?

931. Geraldo, andaremos ajudando quem não precisa?

Embora esta perífrase seja basicamente iterativa, em algumas frases parece que temos os aspectos cursivo e durativo em vez do iterativo. Isto parece ocorrer apenas com verbos indicadores de processos, principalmente com processos télicos que tenham objeto singular (exemplos 932 e 933); processos que não aceitam descontinuidade, tais como amar, viver, respirar, saber (= conhecimento) (exemplos 934 a 936) e verbos transformativos atélicos, desde que tenham sujeitos não agentivos 
(exemplos 937 e 938). O cursivo e o durativo aparecem com verbos de evento, apenas quando esses são tomados como processos e tendo objeto singular (exemplo 939).

932. Márcio anda emoldurando o quadro para você.

933. Jorge anda lendo o livro que lhe dei?

934. Pedro anda amando Maria. Qualquer um percebe isto.

935. Todos andavam vivendo com o mínimo necessário.

936. Marli anda sabendo isto muito bem e pode ajudar você.

937. Abílio anda engordando muito.

938. Bolivar anda enriquecendo a olhos vistos.

939. Os homens andam explodindo a ponte. (com sentido iterativo esta frase seria ruim. Ela só é aceitável com “explodir” significando o processo de preparação para a explosão).

Apesar dos aspectos cursivo e durativo, frases como (932) e (933) deixam entrever uma iteração na medida em que os processos de emoldurar e ler são realizados em períodos descontínuos sucessivos . Fica então a pergunta se aí temos realmente cursivo e durativo ou se o valor iterativo da perífrase se mantém. Para expressar a ideia contida nestas frases com o valor durativo e cursivo, o falante prefere, como mais natural, a perífrase "estar + gerúndio".

Se o verbo transformativo tiver sujeito agente e objeto plural teremos o iterativo (exemplo 940), mas se o objeto for singular (exemplo 941) teremos uma frase do tipo de (932) a (933).

940. Os falsários andam amarelando folhas para dizer que são antigas.

941. Marcos anda arredondando esta pedra para fazer um trabalho escolar.

Devido ao valor iterativo da perífrase, a frase será ruim quando tivermos um verbo de evento, indicador de situação que não se repete para o mesmo ser, com o sujeito (se o verbo é intransitivo) ou o objeto (se o verbo é transitivo) singular e de sentido não genérico. Exemplo:

942.* O bebê anda nascendo sadio.

O que comentamos para a perífrase "andar + gerúndio" vale também para a perífrase ANDAR + A + INFINITIVO. Esta perífrase, entretanto, é muito pouco 
usada no Brasil e, às vezes, as frases soam algo estranhas. Para exemplificação, basta substituir nos exemplos (918) a (942) o "gerúndio" por “a + infinitivo".

\subsection{2 - VIVER + GERÚNDIO}

A perífrase VIVER + GERÚNDIO marca os aspectos imperfectivo, não acabado e habitual com todas as flexões verbais em que é possível. Exemplos.

943. Antônio vive protestando contra as injustiças dos homens.

944. Genivaldo vivia achando objetos na rua.

945. Pedrinho ainda viveria engolindo tudo o que achasse ser comestível, se não tivesse ficado com medo, depois que quase morreu envenenado.

946. Embora Dagoberto viva olhando para mim, nunca se aproximou.

947. Se Jane vivesse pintando como diz, teria muitos quadros prontos.

948. Você me impede de corrigi-lo agora, mas quando seu filho viver chegando tarde da noite, você irá se lamentar.

949. As meninas viverem caminhando pelo bosque é muito bom para a sua saúde.

Nos pretéritos perfeito e mais-que-perfeito do indicativo, a perífrase se desfaz e o que temos é o seguinte: o verbo viver em um destes tempos com seu significado de "ter vida", "passar a existência"; e o verbo no gerúndio indicando o modo como o sujeito viveu, ou a atividade que ele executou durante a vida. Veja exemplos (950) a (953).

950. Seu irmão viveu sonhando ser ator, mas nunca fez nada neste sentido.

951. Benedito viveu consertando móveis para as pessoas.

952. Selma vivera economizando para que depois os filhos esbanjassem tudo.

953. Ulisses vivera criando histórias que alegrassem as crianças.

No futuro do presente, as frases normalmente são ambíguas: temos uma interpretação habitual e outra interpretação de viver (= ter vida) + modo de viver ou atividade realizada durante a vida. A decisão entre uma e outra possibilidade parece que vai depender, em grande parte, do significado do verbo principal que favorecerá uma das duas interpretações. Veja exemplos abaixo. 
954. Você viverá pedindo esmolas. (ter vida + atividade).

955. Viveremos esperando que você volte. (ter vida + atividade).

956. Quando vier morar aqui, Valdete viverá caminhando pelos bosques a procura de plantas. (habitual).

Quando o sujeito da frase é algo que não pode "ter vida", a interpretação favorecida é a habitual, mas temos frases pouco naturais, provavelmente porque, quase nunca ou nunca, são utilizadas pelos falantes, apesar de possíveis (exemplo 957).

957. ? Viverão nascendo ervas daninhas no meu gramado.

Devido ao valor iterativo da perífrase, a frase será ruim, quando tivermos um verbo de evento, indicador de situação que não se repete para o mesmo ser, com o sujeito (se o verbo é intransitivo) ou o objeto (se o verbo é transitivo) singular e de sentido não genérico. Exemplos:

958. * $\quad *$ bezerrinho vive nascendo perfeito.

959. * $\mathrm{O}$ vaso vive quebrando. (Esta frase só seria possível se imaginássemos que o vaso se quebra e é consertado repetidas vezes).

O que comentamos para a perífrase "viver + gerúndio" vale também para a perífrase VIVER + A + INFINITIVO. Entretanto, como esta praticamente não é usada no Brasil, as frases soam um pouco estranhas. Para exemplificação, basta substituir nos exemplos (943) a (959) o "gerúndio" por “a + infinitivo".

\subsection{3 - VIVER + PARTICÍPIO}

A perífrase VIVER + PARTICÍPIO marca o aspecto habitual com todas as flexões verbais em que é possível. Marca os aspectos imperfectivo e não acabado com todos os tempos, exceto com os pretéritos perfeito e mais-que-perfeito do indicativo onde temos aspecto perfectivo.

Em realidade, nesta construção o particípio funciona como um adjetivo em função predicativa, e o verbo viver é um verbo relacional que marca a habitualidade pelo seu semantema. Compare-se para comprovação desta colocação exemplos como (960) e (961) abaixo.

960. João vive calado. (imperfectivo, não acabado, habitual).

961. João vive contente. (imperfectivo, não acabado, habitual). 
Vejamos alguns exemplos com a construção "viver + particípio".

962. Paulo vive perdido em fantasias. (imperfectivo, não acabado, habitual).

963. Esta porta vivia aberta quando a senhora não estava aqui. (imperfectivo, não acabado, habitual).

964. Antônio viveria aborrecido, se não tivesse aprendido a tratar com os problemas sem se envolver neles. (imperfectivo, não acabado, habitual).

965. Embora Alexandre viva rodeado de amigos, sente-se solitário. (imperfectivo, não acabado, habitual).

966. Se o menino vivesse queimado por causa de suas experiências, você poderia dizer alguma coisa. (imperfectivo, não acabado, habitual).

Muito frequentemente o verbo "viver" deixa de ter valor relacional e readquire seu valor nocional de "ter vida", "passar a vida" e o particípio, então, normalmente indica o modo de vida ou algo feito na vida ou num período dela. Isto acontece principalmente nos pretéritos perfeito e mais-que-perfeito do indicativo e no futuro do presente. Neste caso, o aspecto indicado é devido à flexão temporal do verbo viver, ou a algum outro fator, como adjuntos adverbiais. Muito frequentemente, as frases são ambíguas admitindo as duas interpretações. Exemplos:

967. Antônio viveu aborrecido com o mundo. (perfectivo, acabado).

968. José vivera preso às responsabilidades com a família para, no fim, receber ingratidão. (perfectivo, acabado).

969. Se você não fizer algo agora, viverá dominado por eles o resto de seus dias. (não aspecto).

970. Se você viver aborrecido com as coisas, o que ganhará com isso? (ambígua).

971. Vivendo calado desse jeito você deixa todos preocupados. (ambígua. A tendência é para interpretar viver = ter vida).

No futuro do presente, se a frase é interrogativa, temos sentido presente e os aspectos expressos são o imperfectivo, o não acabado e o habitual. Exemplo: 
972. Antônio viverá calado, porque não concorda com nossas ideias?

Considerando que "viver" é um verbo relacional e o "particípio" funciona como adjetivo, quando "viver + particípio" marca o aspecto habitual, e que, nas construções de "viver + adjetivo", também temos o habitual; podemos afirmar que o verbo "viver", pelo seu semantema, marca o habitual para os estados.

\subsection{4 - COSTUMAR + INFINITIVO}

A perífrase COSTUMAR + INFINITIVO marca o aspecto habitual com todas as flexões verbais em que é possível. Os demais aspectos presentes na frase são devidos à flexão temporal e outros fatores. Vejamos alguns exemplos:

973. O supermercado costuma abrir antes das oito horas. (imperfectivo, não acabado, habitual).

974. Terezinha costumava pregar os botões para mim, quando eu morava em São Paulo. (imperfectivo, não acabado, habitual).

975. Papai costumará chegar às oito horas, depois que passar para o novo trabalho. (habitual).

976. Fausto costumaria fechar a porta se não tivesse você para fazê-lo. (imperfectivo, não acabado, habitual).

977. Embora costume consertar carros rapidamente, Tininho não aprontou o meu a tempo. (imperfectivo, não acabado, habitual).

978. Se seu filho costumasse vir aqui, eu lhe diria. (imperfectivo, não acabado, habitual).

979. Quando os homens costumarem morrer por um ideal, teremos mais fé neste mundo. (habitual).

980. Se aqui costumar chover muito, vou adorar este lugar. (imperfectivo, não acabado, habitual).

981. Os soldados costumarem explodir as pontes para evitar o avanço do inimigo, nem sempre é uma boa tática. (habitual).

982. Costumando pagar suas promessas, Cláudia não pensou que alguém pudesse faltar com a palavra. (habitual).

Nos pretéritos perfeito e mais-que-perfeito do indicativo, sistematicamente, e no futuro do presente com bastante frequência, as frases são ambíguas e podem ter duas interpretações. A primeira, própria da perífrase, de que a pessoa teve ou terá o costume de fazer algo. Neste caso, teremos, com os pretéritos os aspectos perfectivo, acabado e habitual e, com o futuro do presente, apenas o habitual. Na 
segunda interpretação, temos o significado de que a pessoa "acostumou-se" ou "se acostumará" a fazer algo. Aqui teremos o aspecto devido à flexão temporal: perfectivo e acabado (com os pretéritos) e não aspecto (com o futuro). Nesta segunda interpretação, parece-nos que temos não o verbo "costumar", mas uma forma dialetal popular de "acostumar-se" com o /o/ pretônico pronunciado como [u], que é usada também em outros tempos, como o presente do indicativo (exemplo 990). Observe-se a ambiguidade a que nos referimos nos exemplos (983) a (990) abaixo.

983. O Sr. José costumou levantar cedo.

984. Papai costumou comprar neste supermercado.

985. Celina costumou ficar na sala depois do almoço.

986. O trem costumara sair no horário.

987. O menino costumara pedir balas ao avô.

988. As pessoas costumarão respirar corretamente.

989. Sérgio costumará limpar os pés antes de entrar.

990. Não se preocupe, com o tempo ela costuma morar aqui.

Nos pretéritos perfeito e mais-que-perfeito, devido ao pouco ou nenhum uso de tais formas, para indicar um hábito acabado, há uma tendência para considerar mais a interpretação de "acostumar-se". Se colocamos um adjunto adverbial como "sempre" nas frases com estes tempos, temos o aspecto habitual sem dúvida (exemplos 991 a e 992 a). Neste caso, entretanto, o aspecto é marcado pelo adjunto adverbial, e o verbo costumar é perfeitamente dispensável na expressão do pensamento em questão (exemplos 991 b e 992 b).

991. a - O trem sempre costumou partir no horário.

b - O trem sempre partiu no horário.

992. a - Eunice sempre costumou resfriar-se, quando tomava sereno.

b - Eunice sempre se resfriou, quando tomava sereno.

8.6.5 - USAR + INFINITIVO

A perífrase USAR + INFINITIVO marca o aspecto habitual com todas as flexões verbais, conforme se pode observar nos exemplos abaixo. Os demais aspectos presentes na frase são devidos a outros fatores, principalmente à flexão temporal.

993. Mamãe usa limpar a casa de tarde. (imperfectivo, não acabado, habitual). 
994. Madalena usava colocar uma flor sobre sua mesa do escritório. (imperfectivo, habitual).

995. Os homens já usaram beijar as mãos às senhoras. (perfectivo, acabado, habitual).

996. Depois deste problema, ele usará conferir todas as listas de mercadorias. (habitual).

997. Se eu não tivesse tanto trabalho usaria tirar uma soneca depois do almoço. (habitual).

998. Embora ele use avisar que vai chegar mais tarde, sempre fico preocupada. (imperfectivo, não acabado, habitual).

999. Mesmo que Álvaro usasse levar salgados do bar para os filhos, vocês não tinham nada com isso. (imperfectivo, não acabado, habitual).

1.000. Usar trancar a porta ao sair é uma boa coisa. (habitual).

Esta perífrase, que a nosso ver tem o mesmo significado de "costumar + infinitivo", é pouco usada.

\subsection{6 - HABITUAR-SE + A + INFINITIVO}

A perífrase HABITUAR-SE + A + INFINITIVO, a nosso ver não marca qualquer aspecto.

Castilho (1967, p.94) afirma que esta perífrase, com verbos atélicos, expressa o aspecto Iterativo Imperfectivo e apresenta apenas um exemplo que transcrevemos abaixo, sob o número (1.001).

\subsection{1. "Habituou-se a estudar pela manhã."}

O verbo "habituar-se" significa “adquirir o hábito de...". Possivelmente por extrapolação, o autor deve ter concluído que, se adquiriu o hábito de estudar pela manhã, então a situação de "estudar pela manhã" se repete e temos a iteratividade. Esse tipo de raciocínio, entretanto, não deve ser feito, pois a construção em si não marca a iteratividade gramaticalmente, com referência explícita à repetição da situação, atribuindo-lhe uma duração descontínua, embora logicamente saibamos que se o hábito foi criado a situação se repetirá.

Os aspectos que aparecem em frases com esta perífrase não se devem a ela, mas a outros meio de expressão do aspecto, como as flexões temporais e adjuntos adverbiais. Veja os exemplos (1.002) a (1.004). 
1.002. Eles reclamam, mas sempre se habituam a obedecer o regulamento. (imperfectivo, não acabado, habitual) - O aspeto é devido ao presente do indicativo e ao adjunto adverbial "sempre".

1.003. Quando estive lá, Waldemar habituava-se a engolir apenas depois de mastigar trinta vezes a porção de alimento. (imperfectivo, cursivo, não acabado, durativo) - O aspecto é devido ao pretérito imperfeito do indicativo

1.004. Cristina habituou-se a tomar leite antes de dormir. (perfectivo, acabado) - O aspecto é devido ao pretérito perfeito do indicativo

\subsection{7 - TORNAR/VOLTAR + A + INFINITIVO}

Poder-se-ia pensar que as perífrases TORNAR + A + INFINITIVO e VOLTAR $+\mathrm{A}+$ INFINITIVO marcassem o aspecto iterativo, uma vez que expressam, respectivamente o fato de uma situação ter uma segunda realização, ou passar a ser realizada outra vez após um período de interrupção. Estas perífrases, entretanto, não marcam aspecto iterativo, porque, apesar de haver repetição da situação, elas se referem apenas a uma realização da situação e, portanto, não lhe atribuem uma duração descontínua.

$\mathrm{O}$ aspecto presente em frases construídas com estas perífrases não se deve a elas, mas normalmente à flexão temporal e a elementos adverbiais (adjuntos ou orações). Geralmente temos os aspectos imperfectivo, não acabado e habitual nos presentes e nos pretéritos imperfeitos do indicativo e do subjuntivo por influência de adjuntos ou orações adverbiais e o perfectivo nos pretéritos perfeito e maisque-perfeito do indicativo. Veja exemplos (1.005) a (1.010).

1.005. Quando Antônio está na cidade Raul volta a chegar tarde em casa.

1.006. Célia fazia regime, mas sempre tornava a engordar.

1.007. Embora Paulo torne a adoecer cada vez que bebe, não se decide a deixar este vício.

1.008. Todo ano você volta a estudar e desiste no meio do período.

1.009. Tornou a chover de tarde.

1.010. Quando cheguei da viagem, meu irmão voltara a trabalhar.

\section{7 - AS PERÍFRASES DE FICAR}

No estudo da expressão do aspecto pelas perífrases de ficar, é preciso considerar três possibilidades de significado ou emprego deste verbo, pois o aspecto 
expresso irá variar de acordo com o significado ou emprego em que ele se apresenta. Estas três possibilidades são:

1. O verbo ficar significa "permanecer ou conservar-se em determinada situação";

2. O verbo ficar significa "tornar-se", "vir a estar em determinada situação" (geralmente um estado);

3. O verbo ficar, na condição de auxiliar, marca a iteração da situação.

Quando o verbo "ficar” se apresenta com o primeiro significado, a perífrase marca o aspecto durativo principalmente se temos explícito, na frase ou no contexto, o período de tempo em que se permaneceu ou permanecerá na situação indicada. O verbo ficar pode ocorrer com o primeiro sentido nas perífrases FICAR + GERÚNDIO (cf. exemplos 1011 a 1015), FICAR + PARTICÍPIO (cf. exemplos 1.016 a 1.019$)$.

1.011. Você fica olhando as crianças, enquanto eu vou fazer compras.

1.012. André ficará orientando as pessoas que chegam.

1.013. É preciso que você o fique esperando aqui.

1.014. Se eu ficar assistindo televisão até tarde hoje, não levantarei cedo amanhã para ir à escola.

1.015. Dagoberto ficou estudando a noite toda. (perfectivo, durativo).

1.016. Não gosto quando você fica calado, olhando para mim.

1.017. Selma ficou parada na porta até que a notassem.

1.018. Prometo-lhe que ficarei sentada durante o espetáculo.

1.019. César queria que eu ficasse escondido aqui, ouvindo o que as pessoas diziam.

Na perífrase "ficar + particípio", o particípio vale por um adjetivo e o verbo ficar funciona como verbo relacional exatamente como em construções do tipo "ficar + adjetivo".

No pretérito imperfeito do indicativo, parece que só obtemos frases com valor iterativo ou habitual.

Quando o verbo "ficar" tem o primeiro significado, a presença de elementos adverbiais temporais (adjuntos ou orações) ou de frequência, normalmente leva à expressão do habitual. Nestes casos, a situação que se repete é vista como durativa. Veja exemplos (1.020 a 1.023). 
1.020. Todos os dias ele fica esperando a filha na porta da escola.

1.021. Jorge sempre fica calado durante as reuniões e depois diz que não o deixamos opinar.

1.022. Embora Celina fique ouvindo quando falo com ela, nunca me atende.

1.023. O fato de eu ficar ajoelhado quando rezo, pareceu-lhes estranho.

Na perífrase FICAR + POR + INFINITIVO, o verbo ficar parece apresentar sempre o primeiro sentido (conservar-se em determinada situação). "Por + infinitivo" expressa um estado que representará uma situação referencial. Esta perífrase, com o significado especificado, marca o aspecto durativo (exemplos 1.024 a 1.027), ou o habitual com o auxílio de elementos adverbiais (exemplos 1.028 a 1.030) para a situação referencial, nas mesmas condições especificadas acima para "ficar + gerúndio ou particípio". A situação narrada é sempre marcada pelo conjunto "por + infinitivo", como não começada.

1.024. Este livo fica por ler até que eu tenha tempo para isto.

1.025. É bom que este caso fique por resolver, enquanto não temos melhores provas.

1.026. Seu processo ficará por despachar até que você traga o documento que falta.

1.027. Esta mesa ficou por arrumar a semana toda. (perfectivo, durativo).

1.028. Quando o serviço é muito a lista dos pagamentos fica por conferir. (habitual).

1.029. Embora o relatório fique por bater todo sábado, o presidente nunca deixou de recebê-lo na segunda à tarde.

1.030. Esta questão sempre ficou por decidir, mas hoje temos de encará-la.

Quando não se especifica de alguma forma, na frase ou no contexto, o período de permanência na situação, temos a implicação lógica de que o que "ficou ou ficará por fazer" “estava ou está por fazer”. Esta implicação leva a interpretar o verbo "ficar" como equivalente a "continuar" o que pode nos levar a uma análise aspectual semelhante à que temos para "continuar + por + fazer" (cf. item 8.9). As frases (1.031) a (1.033) são exemplos do que acabamos de dizer.

1.031. Se você demorar muito, estes caixotes ficam por fechar. (S.R.: estado de "por fechar" - começado; S.N.: fechar - não começado). 
1.032. Como não tive tempo, este livro ficou por ler. (S.R.: estado de "por ler": perfectivo; S.N.: ler - não começado).

1.033. Seu quarto ficará por limpar, se você não vier me ajudar. (S.R.: estado de "por limpar": começado; S.N.: limpar - não começado).

Quando o verbo "ficar” apresenta o segundo significado (tornar-se, vir a estar em determinada situação), o aspecto indicado nada tem a ver com a perífrase em si, mas se deve à flexão temporal e à influência de outros elementos, principalmente os adjuntos e orações adverbiais de tempo. O verbo ficar apresenta este segundo sentido quase só na perífrase FICAR + PARTICÍPIO. Veja os exemplos (1.034) a (1.038).

1.034. Meu cachorro fica apavorado quando ouve os estouros dos fogos de artifício. (imperfectivo, não acabado, habitual) - Aspecto devido ao presente do indicativo e à influência da oração adverbial temporal.

1.035. Margarete sempre ficava desnorteada com as brigas dos filhos. (imperfectivo, não acabado, habitual) - Aspecto devido ao pretérito imperfeito do indicativo e ao adjunto adverbial "sempre".

1.036. O documento ficou rasgado em pedacinhos. (perfectivo, acabado) - Aspecto devido ao pretérito perfeito do indicativo.

1.037. Este elemento ficará prensado entre as duas chapas de metal. (não aspecto) - Devido ao tempo futuro.

1.038. Embora minha mãe fique preocupada quando demoramos muito, Renato nunca se dá ao trabalho de telefonar avisando. (imperfectivo, não acabado, habitual) - Aspecto devido ao presente do subjuntivo com valor temporal de presente e à influência da oração temporal.

Nos presentes e pretéritos imperfeitos do indicativo e do subjuntivo há uma tendência para o habitual. O durativo e cursivo, nestes tempos, só parecem ocorrer (quando o verbo ficar tem o segundo sentido), quando se tem a combinação de "estar + gerúndio" e "ficar + particípio" (ver exemplo 1039).

1.039. O rapaz está ficando apavorado com estas ameaças. (imperfectivo, cursivo, não acabado, durativo).

Excetuada a perífrase "ficar + particípio", o verbo ficar só aparece com o segundo significado na perífrase "ficar + gerúndio", quando o verbo principal é um verbo estático não de estado como nas frases (1040) e (1041). 
1.040. Arquibaldo ficou sabendo de tudo. (perfectivo, acabado) - Aspecto devido ao pretérito perfeito do indicativo

1.041. Se você fizer isto, o inimigo fica tendo uma vantagem sobre nós. (não aspecto) - Porque o presente do indicativo tem valor de futuro.

$\mathrm{O}$ verbo ficar tem o terceiro significado apenas com a perífrase FICAR + GERÚNDIO que, neste caso, marca o aspecto iterativo com qualquer flexão temporal em que seja possível. Veja exemplos (1.042) a (1.048) abaixo.

1.042. Você fica falando isto que acabará tendo problemas. (imperfectivo, não acabado, iterativo).

1.043. Você ficava telefonando para o pensionato, mesmo depois que lhe pedi para não fazê-lo. (imperfectivo, não acabado, iterativo).

1.044. Celso ficou escrevendo para a revista até lhe darem uma resposta. (perfectivo, iterativo).

1.045. Se o gerente não recebê-lo, ele ficará vindo aqui e insistindo. (iterativo).

1.046. Embora Roberto fique me olhando, nunca me dirigiu a palavra. (imperfectivo, não acabado, iterativo).

1.047. Embora ele ficasse pedindo para eu ajudá-lo, nunca o achei chato. (imperfectivo, não acabado, iterativo).

1.048. Se você ficar indo à beira do rio, nunca mais deixo você passear na fazenda. (iterativo).

Com os verbos de evento a perífrase ficar + gerúndio normalmente tem valor iterativo (cf. exemplos 1.049 e 1.050).

1.049. Por que você fica partindo sem avisar? (imperfectivo, acabado, iterativo).

1.050. Você ficou chegando atrasado até que o despediram. (perfectivo, iterativo).

A perífrase FICAR + A + INFINITIVO, que é pouco usada, se comporta exatamente como a perífrase "ficar + gerúndio" em todos os casos.

$\mathrm{O}$ verbo ficar quando funcionando como relacional em construções do tipo "ficar + atributo" se comporta, em todos os casos, exatamente como em "ficar + particípio", onde o particípio sempre tem valor de adjetivo. 
Os diferentes valores das perífrases de ficar nem sempre são claramente distinguíveis e, muitas vezes, a frase parece ambígua.

\section{8 - AS PERÍFRASES DE PERMANECER}

As perífrases PERMANECER + GERÚNDIO e PERMANECER + PARTICÍPIO têm valores aspectuais diversos conforme o verbo permanecer signifique: 1) conservar-se; 2) continuar a...

Se o verbo permanecer tem o sentido de "conservar-se", a perífrase expressa o aspecto durativo, principalmente se temos explícito na frase ou no contexto o período de tempo em que se permaneceu na situação indicada. Veja os exemplos (1051) a (1058) abaixo.

1.051. O presidente da Câmara permanece falando há mais de uma hora. (imperfectivo, não acabado, durativo).

1.052. Este homem permaneceu governando o país por duas décadas. (perfectivo, acabado, durativo).

1.053. Meu filho permanecerá atendendo os compradores por duas horas, depois um de vocês o substituirá. (durativo).

1.054. É indispensável que você permaneça vigiando a noite toda. (durativo).

1.055. Desde ontem ele permanece sentado ali. (imperfectivo, não acabado, durativo).

1.056. Jair permaneceu calado durante a festa. (perfectivo, durativo).

1.057. Você permanecerá montado neste cavalete, enquanto durar o primeiro ato. (durativo).

1.058. Se Aurélio permanecesse escondido por uns dois anos, talvez as pessoas se esquecessem dele. (durativo).

Se o verbo permanecer tem o sentido de "continuar a...", temos o aspecto começado ou não acabado para a situação referida pelo gerúndio ou particípio, quer ela seja vista como referencial quer seja vista como narrada. Ex.:

1.059. Este grande atleta permanece competindo até hoje. (imperfectivo, cursivo, não acabado, durativo).

1.060. O menino João Carlos permanece desaparecido até hoje. (imperfectivo, cursivo, não acabado, durativo).

1.061. O candidato permaneceu expondo seus planos, apesar da reação do povo. 
a - S.R.: permanecer expondo - perfectivo, acabado.

b - S.N.: expor - não acabado.

1.062. Plínio permaneceu calado, embora todos insistissem para que ele dissesse o que havia acontecido.

a - S.R.: permanecer calado - perfectivo, acabado.

b - S.N.: estado de calado - não acabado.

1.063. Egberto permanecerá tocando, quando começarmos a distribuir o folheto com a letra da música. (começado).

Como se pode observar nos exemplos dados, os dois valores de permanecer nem sempre são claramente separáveis, o que dificulta a análise em muitos casos.

Por influência de elementos adverbiais (adjuntos ou orações), temos o habitual com as perífrases de permanecer. Neste caso, cada realização da situação é vista como durativa ou simplesmente começada conforme o caso. Exemplos:

1.064. Romeu sempre permanece calado durante as reuniões. (imperfectivo, não acabado, habitual) - Cada realização da situação é durativa.

1.065. Quando havia muito serviço Valério permanecia emoldurando quadros até mais tarde. (imperfectivo, não acabado, habitual) Cada realização da situação é começada e durativa.

1.066. Embora Dirce e Raul permaneçam conversando muito tempo quando se encontram, não são grandes amigos. (imperfectivo, não acabado, habitual) - Cada realização da situação é durativa.

A perífrase PERMANECER + A + INFINITIVO, menos usada que "permanecer + gerúndio", se comporta exatamente como esta no que diz respeito à expressão do aspecto. $\mathrm{O}$ verbo permanecer, usado como relacional em construções do tipo "permanecer + atributo", se comporta exatamente como na perífrase "permanecer + particípio" (onde particípio tem valor de um adjetivo) no que respeita à expressão do aspecto.

As frases com as perífrases de permanecer são pouco frequentes, uma vez que os falantes preferem expor os mesmos pensamentos valendo-se das perífrases de estar, ficar e continuar.

\section{9 - As PERÍFrASES DE CONTINUAR, PROSSEGUIR E SEGUIR}

As perífrases que têm continuar e prosseguir como auxiliares marcam os aspectos começado ou não acabado e durativo para a situação expressa pelo verbo 
principal, quer ela seja vista como situação narrada, quer seja vista como situação referencial, com qualquer flexão verbal. Como aspecto durativo + evento $=$ iteratividade; quando temos estas condições, em vez do durativo temos o iterativo.

Vejamos alguns exemplos para cada perífrase.

\subsection{1 - CONTINUAR + GERÚNDIO}

1.067. Continuamos estudando comunicação. (imperfectivo, cursivo, não acabado, durativo).

1.068. Apesar dos avisos, Ricardo continuava chegando atrasado. (imperfectivo, não acabado, iterativo).

1.069. Os ônibus continuarão partindo às 6 horas. (imperfectivo, começado, iterativo).

1.070. Continue fazendo o exercício. (imperfectivo, cursivo, começado, durativo).

1.071. Rafael continuou procurando o documento embora eu lhe tivesse dito que podia deixar aquilo de lado.

a) S.R.: continuar procurando - perfectivo, acabado.

b) S.N.: procurar - não acabado, durativo.

1.072. Embora Marcos continuasse amando Marina, resolveu não procurá-la mais. (imperfectivo, cursivo, não acabado, durativo).

A perífrase CONTINUAR + A + INFINITIVO, que é muito pouco usada, tem o mesmo valor que "continuar + gerúndio". Para exemplificação, basta substituir nas frases (1.067) a (1.072) o gerúndio por “a + infinitivo".

\subsection{2 - CONTINUAR + PARTICÍPIO}

1.073. Meu cachorro continua desaparecido. (imperfectivo, cursivo, não acabado, durativo).

1.074. Quando voltei, o menino continuava acordado. (imperfectivo, cursivo, não acabado, durativo).

1.075. Eu chamei José às seis horas, mas ele continuou deitado.

a) S.R.: continuar deitado - perfectivo.

b) S.N.: estado de deitado - não acabado, durativo.

1.076. Embora a exibição deste filme continue proibida, vão exibi-lo para os alunos do curso de artes. (imperfectivo, cursivo, não acabado, durativo). 
1.077. Paulo disse que continuará escondido até que tudo se acalme. (imperfectivo, cursivo, não acabado, durativo).

Como o particípio sempre indica um estado, a perífrase "continuar + particípio" não aceita a interpretação iterativa.

Quando utilizado como verbo relacional, em construções do tipo "continuar + atributo", o verbo continuar expressa os aspectos não acabado e durativo, da mesma forma que na perífrase "continuar + particípio" onde o particípio tem sempre um valor adjetivo.

\subsection{3 - CONTINUAR + POR + INFINITIVO}

Nesta perífrase, além dos aspectos já especificados acima, teremos sempre o aspecto não começado para a situação narrada, que é a situação expressa pelo verbo no infinitivo. Também aqui "POR + INFINITIVO" tem valor adjetivo, indicando o estado de algo antes da realização da situação expressa pelo infinitivo. Por esta razão, não temos a interpretação iterativa também com esta perífrase.

1.078. Seu vestido continua por arrematar, pois não tive tempo.

a) S.R.: Estado de "por arrematar" - imperfectivo, cursivo, não acabado, durativo.

b) S.N.: arrematar - não começado.

1.079. Os móveis continuavam por envernizar, quando fui lá hoje cedo. a) S.R.: estado de "por envernizar" - imperfectivo, cursivo, não acabado, durativo.

b) S.N.: envernizar - não começado.

1.080. Esta máquina continuará por consertar até que você me pague o conserto das outras.

a) S.R.: estado de "por consertar": imperfectivo, cursivo, não acabado, durativo.

b) S.N.: consertar - não começado.

1.081. Embora a casa continue por pintar já fizemos vários arranjos.

a) S.R.: estado de "por pintar" - imperfectivo, cursivo, não acabado, durativo.

b) S.N.: pintar - não começado.

Quando essa perífrase é usada nos pretéritos perfeito e mais-que-perfeito do indicativo, temos um caso bastante particular, porque há referência a três situações 
ao mesmo tempo: a) a situação de "continuar + por + infinitivo" (situação referencial); b) a situação que é o estado indicado em "por + infinitivo" (situação narrada 1); c) a situação expressa pelo "infinitivo" (situação narrada 2). Veja exemplos 1082 e 1083. Nos demais tempos (cf. exemplos 1078 a 1081), não há razão para distinção entre a situação narrada 1 e a referencial, porque elas são simultâneas.

1.082. Apesar da ordem do chefe, o arquivo continuou por organizar.

a) S.R.: continuar por organizar - perfectivo, acabado.

b) S.N.1: estado de "por organizar" - não acabado, durativo.

c) S.N.2: organizar - não começado.

1.083. Mesmo depois de obtida a verba, o ginásio continuou por construir, por causa de divergências entre os diretores.

a) S.R.: continuar por construir - perfectivo, acabado.

b) S.N.1: estado de "por construir" - não acabado, durativo.

c) S.N.2: construir - não começado.

8.9.4 - PROSSEGUIR + GERÚNDIO

1.084. Os peixes de lagoa prosseguem morrendo sem que nada seja feito. (imperfectivo, cursivo, não acabado, durativo).

1.085. Os homens prosseguirão cavando noite adentro, para que tudo seja preparado a tempo. (imperfectivo, cursivo, não acabado, durativo).

1.086. Embora prossiga chovendo aqui em Minas, as chuvas já se tornaram mais leves e sem ventos fortes. (imperfectivo, cursivo, não acabado, durativo).

1.087. Como todos pediram, o conferencista prosseguiu falando apesar da hora avançada.

a) S.R.: prosseguir falando - perfectivo, acabado.

b) S.N.: falar - não acabado, durativo.

A perífrase "prosseguir + gerúndio" é bem menos usada que "continuar + gerúndio" e parece não ocorrer com a interpretação iterativa.

\subsection{5 - SEGUIR + GERÚNDIO OU A + INFINITIVO}

As perífrases de "seguir" são muito pouco usadas, particularmente "seguir $+\mathrm{a}+$ infinitivo". 
Estas perífrases só marcam os aspectos durativo e começado ou não acabado, quando "seguir" tem o significado de "continuar" (cf. exemplos 1.088 a 1.090). Se seguir não se apresenta com este significado, a frase é interpretada como indicando: a) a situação que será realizada em seguimento a outra explícita ou não; b) que algo ou alguém irá para algum lugar, fazendo alguma coisa ou irá de um determinado modo. Neste caso, o aspecto depende da flexão temporal e outros fatores.

1.088. Raquel segue engordando apesar do regime que está fazendo. (imperfectivo, cursivo, não acabado, durativo).

1.089. Não importa o que digam, seguirei odiando você até o fim da minha vida. (imperfectivo, cursivo, começado, durativo).

1.090. É importante que você siga vigiando-o para mim. (imperfectivo, cursivo, começado, durativo).

Normalmente o falante usa pouco esta perífrase por preferir as de "continuar" e "ficar".

É interessante notar que, por causa do significado das perífrases de continuar, prosseguir e seguir, quando elas têm sentido futuro há uma ligação presente ${ }^{\circledR}$ futuro.

É frequente termos com estas perífrases frases de sentido habitual, por influência de elementos adverbiais (adjuntos e orações). Isto ocorre principalmente nos presentes e pretéritos imperfeitos do indicativo e do subjuntivo. Nestes casos, cada realização da situação é vista como começada e durativa. Veja exemplos (1.091) a (1.095).

1.091. Quando há muito serviço, Alberto continua conferindo as notas depois do expediente. (imperfectivo, não acabado, habitual).

1.092. Quando eu entrava na biblioteca, ele prosseguia lendo, como se ninguém tivesse entrado ali. (imperfectivo, não acabado, habitual).

1.093. Embora Joana sempre continuasse trabalhando após o expediente, para que nada ficasse atrasado, o chefe nunca lhe agradeceu a boa vontade. (imperfectivo, não acabado, habitual).

1.094. Embora todos os dias os rapazes prossigam nadando após a aula, o diretor do clube não acha ruim. (imperfectivo, não acabado, habitual).

1.095. Quando vou visitá-lo na clínica, ele segue falando sozinho como se nem tivesse percebido minha presença. (imperfectivo, não acabado, habitual). 
As perífrases de continuar, prosseguir e seguir, principalmente as de continuar, deixam claro que uma situação que já estava em realização antes de um dado momento não foi interrompida como se esperava.

\subsection{0 - As PERÍfrases DE DEIXAR}

\subsection{1 - DEIXAR + GERÚNDIO/DEIXAR + A + INFINITIVO/DEIXAR + INFINITIVO}

As perífrases DEIXAR + GERÚNDIO, DEIXAR + A + INFINITIVO e DEIXAR + INFINITIVO não marcam qualquer aspecto.

Nas duas primeiras (deixar + gerúndio ou $+a+$ infinitivo), não temos em realidade uma perífrase, mas o verbo "deixar" indicando que alguém se afasta (fisicamente ou não) de outro ser que permanece realizando uma situação indicada pelo "gerúndio" ou "a + infinitivo". O verbo "deixar" terá o aspecto devido à flexão verbal e/ou a outros fatores, enquanto a situação expressa pela forma nominal será sempre apresentada como imperfectiva, cursiva, começada ou não acabada e durativa (cf. exemplos 1.096 a 1.099). Em "deixar + infinitivo", deixar significa que se consente, que se permite, que não se coloca obstáculo à realização da situação expressa pelo infinitivo. Aqui também, deixar tem o aspecto devido à flexão verbal e/ou outros fatores enquanto a situação expressa pelo infinitivo não tem aspecto atualizado. Veja os exemplos (1.100) e (1.101). Nos exemplos (1.096) a (1.101) abaixo, os aspectos indicados entre parênteses são do verbo deixar.

1.096. Eleuza sempre me deixa assistindo televisão e vai dormir. (imperfectivo, não acabado, habitual) - Aspecto devido ao presente do indicativo e ao adjunto adverbial sempre. Em cada realização da situação "assistindo" tem o aspecto que indicamos acima.

1.097. Antônio deixou-a limpando a casa e foi ao supermercado. (perfectivo) - Aspecto devido ao pretérito perfeito do indicativo.

1.098. Talvez eu o deixe dormindo e venha visitar você. (não aspecto por causa do presente do subjuntivo com sentido futuro).

1.099. Antônio deixa a massa a endurecer e vai preparar as tintas.

A interpretação mais natural para (1.099) é com os aspectos imperfectivo, não acabado, habitual, mas se usada numa descrição simultânea terá uma interpretação com os aspectos perfectivo e pontual. 
1.100. Seu pai deixou você ir a Caldas Novas? (Perfectivo) - Aspecto devido ao pretérito perfeito do indicativo.

1.101. O chefe não nos deixará sair mais cedo. - (não aspecto devido ao futuro do presente).

\subsection{2 - DEIXAR + DE + INFINITIVO}

A perífrase DEIXAR + DE + INFINITIVO, em si, não marca qualquer aspecto. Ela indica que uma situação que estava em realização foi interrompida, ou que não se realizou ou realizará uma situação que deveria ser realizada. O aspecto que temos em frases com esta perífrase se deve a outros meios de expressão, tais como a flexão verbal e elementos adverbiais (exemplos 1.102 a 1.107).

1.102. Quando está muito cansada, Marina deixa de datilografar e vai fazer outro tipo de trabalho. (imperfectivo, não acabado, habitual) - Aspecto devido ao presente do indicativo e à influência da oração adverbial.

1.103. Quando você deixará de amolar minha paciência? (não aspecto por causa do futuro do presente).

1.104. Marivaldo deixava de assinar o ponto todos os dias. (imperfectivo, não acabado, habitual) - Aspecto devido ao pretérito imperfeito do indicativo e ao adjunto adverbial "todos os dias".

1.105. Vicente, você deixou de assinar o ponto ontem. (perfectivo) Aspecto devido do pretérito perfeito do indicativo.

1.106. Embora Élio deixe de partir quando um filho adoece, nunca atrasou com o trabalho. (imperfectivo, não acabado, habitual) Aspecto devido ao presente do subjuntivo e à oração adverbial temporal.

1.107. É possível que ele deixe de cantar esta música se eu pedir. (não aspecto, porque o presente do subjuntivo tem valor futuro).

Não encontramos exemplos onde, com o verbo nos presentes ou nos pretéritos imperfeitos do indicativo e do subjuntivo, tivéssemos aspecto cursivo.

Quando a perífrase "deixar + de + infinitivo" aparece combinada à perífrase "estar + gerúndio", temos aspecto terminativo com todas as flexões verbais em que a perífrase de estar marca imperfectivo (exemplos 1.108 a 1.111). Se o verbo principal for de evento, a frase fica ambígua e podemos ter uma interpretação iterativa (exemplo 1112), o que nem sempre ocorre (exemplo 1.113). 
1.108. Celso está deixando de fumar. (imperfectivo, terminativo, não acabado).

1.109. Quando fui visitá-lo, Márcio estava deixando de beber. (imperfectivo, terminativo, não acabado).

1.110. Quando você for competir eu já estarei deixando de jogar. (imperfectivo, terminativo, não acabado).

1.111. Embora eu esteja deixando de amar você, creio que nunca o odiarei. (imperfectivo, terminativo, não acabado).

1.112. Rafael está deixando de fechar a porta. (imperfectivo, não acabado, iterativo em uma interpretação ou imperfectivo, terminativo, não acabado, em outra interpretação).

1.113. Aroldo está deixando de chegar atrasado. (imperfectivo, terminativo, não acabado).

Não encontramos exemplos onde, com o verbo nos presentes ou nos pretéritos imperfeitos do indicativo e do subjuntivo (que são as flexões temporais que podem expressar imperfectivo), tivéssemos aspecto terminativo. Parece que os únicos casos em que podemos dizer que este aspecto aparece é com o verbo nos pretéritos imperfeitos em frases como (1.114) e (1.115) abaixo.

1.114. Quando a vi no mês passado, Ana deixava de dançar (= estava deixando de dançar). (imperfectivo, não acabado, terminativo).

1.115. Embora Sérgio deixasse de fumar (= estivesse deixando de fumar) quando o conheci, ele não estava certo se isto era o melhor. (imperfectivo, não acabado, terminativo).

Naturalmente os falantes empregam de preferência a forma entre parênteses.

Para as formas de valor futuro e para os pretéritos perfeito e mais-que-perfeito do indicativo da perífrase "deixar + de + infinitivo", valem os comentários feitos no item 8.12.2 para as mesmas formas da perífrase "acabar + de + infinitivo".

Na perífrase "deixar + de + infinitivo", só podemos falar em aspecto começado para a situação narrada, expressa pelo verbo no infinitivo, quando a perífrase tiver o significado de que uma situação em realização está sendo ou será interrompida. Nos pretéritos perfeito e mais-que-perfeito do indicativo, com esse significado, a situação narrada será acabada, com valor cessativo. ${ }^{8}$

\footnotetext{
${ }^{8}$ É bom que fique claro que o acabado da situação narrada, com os pretéritos perfeito e mais-que-perfeito do indicativo das perífrases "deixar ou parar ou cessar + de + infinitivo", significa apenas que a
} 


\subsection{1 - As PERÍfrases de CESSAR E PARAR}

As perífrases CESSAR + DE + INFINITIVO e PARAR + DE + INFINITIVO não marcam qualquer aspecto para a situação referencial, indicada pelo todo da perífrase, cujo aspecto será devido principalmente à flexão verbal e a outros fatores. A situação narrada, com os pretéritos perfeito e mais-que-perfeito, é acabada, com valor cessativo.135 As frases com a perífrase de "cessar" são sempre algo estranhas, ao que parece, porque normalmente não se diz que alguém cessa algo, mas sim que algo cessa. Isto leva o falante a preferir a perífrase de "parar". Vejamos alguns exemplos.

1.116. Só cessamos de embalar peças quando toca a sirene das dezoito horas. (imperfectivo, não acabado, habitual). - Aspecto devido ao presente do indicativo e à oração adverbial temporal.

1.117. Eles sempre param de trabalhar às dezoito horas. (imperfectivo, não acabado, habitual). - Aspecto devido à flexão temporal e ao adjunto adverbial "sempre".

1.118. Aos domingos, cessávamos de jogar ao anoitecer. (imperfectivo, não acabado, habitual). - Aspecto devido ao pretérito imperfeito do indicativo e ao adjunto adverbial "Aos domingos".

1.119. Parei de comprar neste armazém porque seus preços são mais altos.

a) S.R.: parar de comprar - perfectivo, acabado.

b) S.N.: comprar - acabado.

1.120. É preciso que você pare de dar informações a eles.

a) S.R.: parar de dar informações - não aspecto.

b) S.N.: dar informações: começado ou não acabado.

Quando temos aspecto habitual como em (1.116) a (1.118) em cada realização da situação referencial, a situação narrada é começada.

Quando as duas perífrases, em estudo neste item, aparecem combinadas à perífrase "estar + gerúndio", temos aspecto terminativo com todas as flexões verbais em que a perífrase de estar marca imperfectivo. Veja exemplos (1.121) a (1.125).

situação não está mais em realização, já que não houve o atingimento de um ponto terminal. Portanto, logicamente, mas não gramaticalmente, o acabado que temos com as perífrases "deixar ou parar ou cessar + de + infinitivo" é diferente do acabado que temos, por exemplo, com as perífrases "acabar ou terminar + de + infinitivo", uma vez que nas primeiras temos um ponto de cessamento, de interrupção na realização da situação narrada e não um ponto de término da mesma, como nas últimas. 
1.121. Seu irmão está parando de estudar. (imperfectivo, terminativo, não acabado).

1.122. Os operários estavam cessando de capinar a plantação, quando chegou a ordem para continuarem até mais tarde. (imperfectivo, terminativo, não acabado).

1.123. Estará parando de ventar quando formos colocar os enfeites na rua. (imperfectivo, terminativo, não acabado).

1.124. Embora os homens estejam cessando de caçar os animais, muitas espécies estão seriamente ameaçadas. (imperfectivo, terminativo, não acabado).

1.125. Estarmos parando de comer não significa que a festa esteja no fim. (imperfectivo, terminativo, não acabado).

O aspecto terminativo também parece ser possível com as perífrases "cessar ou parar + de + infinitivo" nos pretéritos imperfeitos do indicativo e do subjuntivo em frases como (1.126) e (1.127) abaixo:

1.126. Quando cheguei ao hospital Jaime cessava de respirar. (= estava cessando de respirar) - (imperfectivo, terminativo, não acabado).

1.127. Embora parasse de chover (= estivesse parando de chover) quando saímos do cinema, ainda nos molhamos um pouco. (imperfectivo, terminativo, não acabado).

Para as formas de valor futuro e para os pretéritos perfeito e mais-que-perfeito do indicativo das perífrases "cessar ou parar + de + infinitivo", valem os comentários feitos para as mesmas formas da perífrase "acabar + de + infinitivo" no item 8.12.2.

\subsection{2 - AS PERÍFRASES DE ACABAR}

\subsection{1 - ACABAR + GERÚNDIO/ ACABAR + POR + INFINITIVO}

As perífrases ACABAR + GERÚNDIO e ACABAR + POR + INFINITIVO não marcam aspecto. Estas duas perífrases expressam um resultado final ou uma consequência. Em virtude desse significado, são frequentes as formas com valor futuro e nenhuma atualização aspectual. $\mathrm{O}$ aspecto atualizado em frases com estas duas perífrases não depende delas, mas de outros fatores, principalmente a flexão verbal e a influência de elementos adverbiais. Vejamos alguns exemplos. 
1.128. Não o amolem muito, ou ele acaba partindo e nos deixando sozinhos aqui. (não aspecto devido ao valor de futuro da forma).

1.129. Você desobedece e sempre acaba por quebrar alguma coisa. (imperfectivo, não acabado, habitual). - Aspecto devido ao presente do indicativo e ao adjunto adverbial "sempre".

1.130. Telma ficava se aprontando tanto que acabava chegando atrasada ao serviço. (imperfectivo, não acabado, habitual). - Aspecto devido ao pretérito imperfeito do indicativo.

1.131. Celina procurou tanto e acabou por comprar um vestido dos mais simples. (perfectivo). - Aspecto devido ao pretérito perfeito do indicativo.

1.132. É possível que acabe concordando com a ideia de vocês. (não aspecto devido ao valor de futuro da forma).

\subsection{2 - ACABAR + DE + INFINITIVO}

A perífrase ACABAR + DE + INFINITIVO apresenta uma série de particularidades que passamos a expor.

Esta perífrase marca o aspecto acabado nos presentes e pretéritos imperfeitos do indicativo e do subjuntivo e nos pretéritos perfeito e mais-que-perfeito do indicativo. Ao lado do aspecto acabado, há também a expressão da noção temporal de passado recente. Vejamos os exemplos (1.133) a (1.138) abaixo.

1.133. O presidente acaba de receber o telegrama. (acabado).

1.134. Gil acabava de pintar sua obra prima. (acabado).

1.135. Acabei de redigir a mensagem que o senhor pediu.

a) S.R.: acabar de redigir - perfectivo, acabado, pontual.

b) S.N.: redigir - acabado.

1.136. Quando the telefonei, ele acabara de ler seu livro. (acabado).

1.137. Embora Rui acabe de assar um bolo, não o comeremos hoje. (acabado).

1.138. Embora Sérgio acabasse de decidir o que faria, não nos revelou nada. (acabado).

Quando o verbo principal é um evento não há qualquer dúvida sobre a presença do aspecto acabado, mas se temos um processo (cf. exemplos 1.134 e 1.137) a frase parece ambígua e, além da interpretação como acabado, podemos ter também uma interpretação em que teríamos os aspectos imperfectivo, não acabado e terminativo. 
Esta última interpretação só é possível nos presentes e pretéritos imperfeitos do indicativo e do subjuntivo, e se torna mais evidente quando algum elemento na frase, ou no contexto, torna esta interpretação mais plausível (cf. exemplos 1.139 a 1.141).

1.139. a - Acabo de escrever uma carta para papai. (acabado). b - -Vânia, o que você está fazendo?

- Acabo de escrever uma carta para papai. (imperfectivo, terminativo, não acabado).

1.140. Quando cheguei em casa, Sérgio acabava de encerar o chão. (imperfectivo, terminativo, não acabado).

1.141. Embora ele acabasse de impermeabilizar o vaso quando cheguei, não sei onde ele conseguiu o material para fazê-lo. (imperfectivo, terminativo, não acabado).

Em (1.139b), o contexto linguístico praticamente exige que se interprete a frase, como expressando uma situação não acabada. Em (1.140) e (1.141), as orações temporais, iniciadas por "quando", exercem o papel de presentificadores para as situações expressas pelos pretéritos imperfeitos, o que favorece a interpretação com os aspectos especificados, embora a frase continue ambígua.

Para que a perífrase "acabar + de + infinitivo" marque o terminativo sem qualquer dubiedade, o falante prefere combiná-la com a perífrase "estar + gerúndio". Neste caso, temos o aspecto terminativo claramente expresso, com todas as flexões verbais, exceto os pretéritos perfeito e mais-que-perfeito do indicativo. Exemplos.

1.142. Manuel está acabando de picar a carne para fazer o estrogonofe. (imperfectivo, terminativo, não acabado).

1.143. Quando voltarmos, Dona Eufrásia estará acabando de fazer o almoço. (imperfectivo, terminativo, não acabado).

1.144. É possível que Ronaldo esteja acabando de encadernar o livro. (imperfectivo, terminativo, não acabado).

1.145. Estar acabando de arrumar a biblioteca deixou-o muito satisfeito. (imperfectivo, terminativo, não acabado).

No futuro do presente, do pretérito e do subjuntivo, nas formas de sentido futuro do presente e pretérito imperfeito do indicativo e do subjuntivo e nos pretéritos perfeito e mais-que-perfeito do indicativo, teremos aspecto terminativo para a situação narrada, expressa pelo infinitivo, se na frase houver um elemento adverbial 
que precise o momento de término da situação. Além disso, nos pretéritos perfeito e mais-que-perfeito, temos também o acabado para a situação narrada. Poder-se-ia supor que nas formas de futuro tivéssemos o aspecto começado ou não acabado para a situação narrada. Isto, entretanto, não é verdade, pois o exame dos exemplos nos mostra que não há nada na frase que nos permite afirmar se a situação está ou não começada (cf. item 4.2.9). A determinação disso depende apenas do conhecimento da realidade, o que evidencia que o aspecto em questão não está gramaticalmente marcado (exemplos 1.146 a 1.150). Se não houver o elemento adverbial referido, não teremos aspecto terminativo para a situação narrada, pois aí a informação será apenas de que a situação acabou ou acabará sem apresentá-la em seu momento de término (exemplos 1.151 e 1.152). Nas formas de futuro, não há aspecto para a situação referencial expressa por "acabar + de + infinitivo" (exemplos 1.146, 1.147 e 1.149 a 1.151), enquanto que, nos pretéritos perfeito e mais-que-perfeito, temos o perfectivo, o acabado e o pontual (exemplos 1.148 e 1.152).

1.146. Esta firma acabará de construir o estádio em junho. (S.N.: terminativo).

1.147. Se não tivesse de ir ao supermercado, eu acabaria de ler este livro ao meio-dia. (S.N.: terminativo).

1.148. Acabei de arrumar a gaveta no exato instante em que o telefone tocou.

a) S.R.: acabar de arrumar - perfectivo, acabado, pontual.

b) S.N.: arrumar - acabado, terminativo.

1.149. Eu aviso você, se acabar de emoldurar seu quadro às três horas. (S.N.: terminativo).

1.150. É possível que eu acabe de conferir estes cálculos às dez horas, assim sendo, é melhor você vir depois do almoço. (S.N.: terminativo).

1.151. Se Deus quiser acabarei de pagar este terreno. (S.N. e S.R.: não aspecto).

1.152. O seu filho acabou de telefonar perguntando por você.

a - S.R.: acabar de telefonar - perfectivo, acabado, pontual.

b - S.N.: telefonar - acabado.

Nos presentes e pretéritos imperfeitos do indicativo e do subjuntivo, podemos ter o habitual para a situação referencial de "acabar + de + infinitivo", por influência de elementos adverbiais. Veja exemplos (1.153) e (1.154). 
1.153. Jorge sempre acaba de atender os fregueses entre dezenove e vinte horas. (imperfectivo, não acabado, habitual).

1.154. Embora todos os dias Sérgio acabasse de conferir as notas bem tarde, naquele dia havia pouco trabalho e ele foi para casa mais cedo. (imperfectivo, não acabado, habitual).

\subsection{3 - As PERÍFRASES DE TERMINAR}

\subsection{1 - TERMINAR + GERÚNDIO}

A perífrase TERMINAR + GERÚNDIO não marca aspecto. Ela indica que alguém terminou, termina ou terminará algo de um determinado modo, indicado pelo verbo no gerúndio. Assim sendo, o aspecto expresso em frases com esta perífrase não depende dela, mas de outros fatores. A situação expressa pelo gerúndio não apresenta qualquer aspecto. Exemplos:

1.155. Frei Genaro sempre termina o sermão propondo um tema para reflexão. (imperfectivo, não acabado, habitual) - Aspecto devido ao presente do indicativo e ao adjunto adverbial "sempre".

1.156. Ele me fez uma porção de desaforos e terminou falando que você não presta. (perfectivo) - Aspecto devido ao pretérito perfeito do indicativo.

Essa perífrase pode também ser usada com valor semelhante ao que especificamos para "acabar + gerúndio" em 8.12.1, mas é pouco usada neste sentido, pois o falante prefere a perífrase de "acabar".

\subsection{3 .2 - TERMINAR + DE + INFINITIVO}

A perífrase TERMINAR + DE + INFINITIVO tem várias particularidades que expomos abaixo. Como se poderá observar, ela apresenta muitas semelhanças com "acabar + de + infinitivo" no que se refere à expressão do aspecto.

No presente e pretérito imperfeito do indicativo e do subjuntivo a perífrase "terminar + de + infinitivo" marca o aspecto terminativo (cf. exemplos 1.157 a 1.160). Nas frases de presente, teremos este aspecto se a frase for usada numa descrição simultânea e, nas de pretérito imperfeito, nós o teremos se na frase houver uma outra situação passada (normalmente expressa por oração adverbial de tempo com o verbo no pretérito perfeito do indicativo) em relação 
à qual a situação expressa pelo pretérito imperfeito é presente, ou um adjunto adverbial que indica um momento do passado, em relação ao qual o término da situação é presente.

1.157. Rogério termina de ler o livro que você lhe emprestou. (imperfectivo, terminativo, não acabado).

1.158. Quando cheguei ao apartamento, Celso terminava de montar as estantes. (imperfectivo, terminativo, não acabado).

1.159. Embora neste instante o governador termine de explicar o porquê da não concessão do aumento, não se pode sentir qual será a reação dos representantes de classe aqui presentes. (imperfectivo, terminativo, não acabado).

1.160. Embora Raul terminasse de compor a música quando estive lá, ele não quis que eu a visse. (imperfectivo, terminativo, não acabado).

Embora se possa expressar o terminativo por esta forma, os falantes preferem fazê-lo combinando a perífrase "terminar + de + infinitivo" com a perífrase "estar + gerúndio". Neste caso, o aspecto fica claramente expresso com todas as flexões verbais, exceto os pretéritos perfeito e mais-que-perfeito do indicativo. Exemplos:

1.161. Rogério está terminando de ler o livro que você lhe emprestou. (imperfectivo, terminativo, não acabado).

1.162. Quando cheguei ao apartamento, Celso estava terminando de montar as estantes. (imperfectivo, terminativo, não acabado).

1.163. Embora neste instante o governador esteja terminando de explicar o porquê da não concessão do aumento, não se pode sentir qual será a reação dos representantes de classe aqui presentes. (imperfectivo, terminativo, não acabado).

1.164. Embora Raul estivesse terminando de compor a música quando estive lá, ele não quis que eu a visse. (imperfectivo, terminativo, não acabado).

1.165. Quando chegarmos ao depósito da loja, os rapazes estarão acabando de embalar as mercadorias. (imperfectivo, terminativo, não acabado).

1.166. É muito bom vocês já estarem terminando de colher as laranjas. (imperfectivo, terminativo, não acabado). 
Se o verbo é de evento e tem sujeito singular (se for intransitivo) ou objeto singular (se for transitivo), a frase será estranha ou exigirá interpretação especial para ser aceita. Veja exemplos (1.167) e (1.168).

1.167. a - * O trem termina de partir. (esta frase só será aceita se interpretada como "O trem acaba de partir", mas os falantes não a utilizam com este sentido, que é mais naturalmente expresso pela perífrase de "acabar").

b - Os exilados terminam de partir. (imperfectivo, terminativo, não acabado).

1.168. a - * Alberto termina de engolir o comprimido. (idem a 1.167a). b - Alberto termina de engolir os docinhos que ganhou. (imperfectivo, terminativo, não acabado).

Frases como (1.167b) e (1.168b) têm sempre, respectivamente, o sentido de que alguns dos seres indicados pelo sujeito já realizaram a ação indicada pelo infinitivo e os últimos estão para realizá-la ou a estão realizando, e que alguém já fez a ação indicada pelo infinitivo com alguns seres ou coisas, indicadas pelo objeto e ainda vai fazê-la, ou está fazendo, com os últimos.

Nos presentes e pretéritos imperfeitos do indicativo e subjuntivo temos, por influência de elementos adverbiais, o habitual para a situação referencial indicada por "terminar + de + infinitivo". Exemplos:

1.169. Quando quer ir ao cinema, Ofrânio termina de atender os clientes mais cedo. (imperfectivo, não acabado, habitual).

1.170. Embora você sempre terminasse de catar o arroz primeiro do que eu, não o fazia bem. (imperfectivo, não acabado, habitual).

No futuro do presente, do pretérito e do subjuntivo, nas formas de sentido futuro do presente e pretérito imperfeito do indicativo e subjuntivo e nos pretéritos perfeito e mais-que-perfeito do indicativo; temos exatamente o mesmo quadro aspectual que especificamos em 8.12.2 para a perífrase "acabar + de + infinitivo" nestes tempos (cf. comentários aos exemplos 1.146 a 1.152). A seguir, damos alguns exemplos com a perífrase "terminar + de + infinitivo".

1.171. Terminarei de envernizar seus móveis às dezesseis horas 0 mais tardar. (S.N.: terminativo). 
1.172. Se você me ajudasse, eu terminaria de capinar o quintal às quatorze horas e iria ao cinema com vocês. (S.N.: terminativo).

1.173. Você termina de medir as terras quinta-feira? (S.N.: terminativo).

1.174. Terminei de engraxar os sapatos exatamente no momento em que você tocou a campanhia.

a - S.R.: terminar de engraxar - perfectivo, acabado, pontual.

b - S.N.: engraxar - acabado, terminativo.

1.175. Se eu terminar de copiar estes dados às dezoito horas, como pretendo, irei à festa. (S.N.: terminativo).

1.176. É preciso que terminemos de fazer o almoço ao meio-dia. (S.N.: terminativo).

1.177. Será que você terminava de guardar as roupas para mim? (S.N. e S.R.: não aspecto).

1.178. É claro que Jorge terminará de sintecar a casa. (S.N. e S.R.: não aspecto).

1.179. Joaquim terminou de empilhar os tijolos; posso pagá-lo?

a - S.R.: terminar de empilhar - perfectivo, acabado, pontual.

b - S.N.: empilhar - acabado.

\subsection{4 - As PERÍFRASES INCEPTIVAS}

\subsection{1 - AS PERÍFRASES DE COMEÇAR E PRINCIPIAR}

Inicialmente é preciso anotar que as perífrases de principiar são pouco usadas e talvez restritas a um registro mais culto, literário mesmo.

As perífrases COMEÇAR + GERÚNDIO e PRINCIPIAR + GERÚNDIO não marcam aspecto, mas indicam que alguém começou, começa ou começará algo de um determinado modo indicado pelo verbo no gerúndio, que indica também a primeira situação de uma série. $O$ aspecto presente em frases com estas perífrases não depende delas, mas de outros fatores, principalmente a flexão verbal de "começar" ou "principiar" . A situação expressa pelo gerúndio não apresenta qualquer aspecto. Exemplos:

1.180. Antônio começa caminhando e depois corre cada vez mais rápido. (imperfectivo, não acabado, habitual).

1.181. Bento começou limpando os vidros e depois passou para os lustres, teto, piso, etc. (perfectivo).

1.182. - Como você vai começar o "show"?

- Talvez eu comece tocando a canção que você fez. (não aspecto). 
1.183. João principiava a cena rodopiando no palco, como se dançasse. (imperfectivo, não acabado, habitual).

As perífrases COMEÇAR + A + INFINITIVO e PRINCIPIAR + A + INFINITIVO apresentam uma série de particularidades que expomos a seguir. Considerando o fato de que a primeira perífrase é mais usada, vamos apresentar a exemplificação sempre com ela, mesmo porque, para termos exemplos com a perífrase de "principiar", é suficiente substituir o verbo "começar" por "principiar” no mesmo tempo.

No presente e pretérito imperfeito do indicativo e subjuntivo, temos o aspecto inceptivo. Isto se as frases com os presentes são usadas em descrição simultânea; e, nas frases com os pretéritos imperfeitos, há a expressão de outra situação passada, normalmente por oração adverbial de tempo com o verbo no pretérito perfeito do indicativo, em relação à qual a situação expressa pelo pretérito imperfeito é presente, ou um adjunto adverbial que indica um momento do passado em relação ao qual o começo da situação é presente. Estes elementos podem não estar na frase, mas no contexto. Exemplos:

1.184. Começam a nascer as primeiras mudas de amor-perfeito. (imperfectivo, inceptivo, não acabado).

1.185. Naquele tempo Nice começava a subir na firma. (imperfectivo, inceptivo, não acabado).

1.186. Começava a chover quando saímos de casa. (imperfectivo, inceptivo, não acabado).

1.187. Embora comece a chover, vamos sair. (imperfectivo, inceptivo, não acabado).

1.188. Embora Gabriel apenas começasse a esculpir a estátua, já se podia notar que seria um belo trabalho. (imperfectivo, inceptivo, não acabado).

Embora o inceptivo possa ser marcado como especificamos acima, o falante prefere fazê-lo combinando as perífrases "começar ou principiar $+\mathrm{a}+$ infinitivo" com a perífrase "estar + gerúndio". Neste caso, temos aspecto inceptivo com todas as flexões verbais, exceto com os pretéritos perfeito e mais-que-perfeito do indicativo. Exemplos:

1.189. Sua roupa está começando a enxugar. (imperfectivo, não acabado, inceptivo).

1.190. Não se preocupe. Quando chegarmos à fazenda o pessoal ainda estará começando a dançar. (imperfectivo, inceptivo, não acabado). 
1.191. Se eu não tivesse ajudado Carlos, agora é que ele estaria começando a espalhar o milho ao sol. (imperfectivo, inceptivo, não acabado).

1.192. Embora esteja começando a escurecer, Gervásia ainda não voltou. (imperfectivo, inceptivo, não acabado).

1.193. Quando a calda estiver começando a dourar, você tira do fogo. (imperfectivo, inceptivo, não acabado).

1.194. Ondina estar começando a fumar deixou seu pai muito triste. (imperfectivo, inceptivo, não acabado).

1.195. Quando fui ver, o pernil estava começando a queimar. (imperfectivo, inceptivo, não acabado).

Nos presentes e pretéritos imperfeitos, podemos ter o habitual para a situação referencial indicada por "começar ou principiar + a + infinitivo" com ou sem a influência de elementos adverbiais. Exemplos:

1.196. A Dra. Lúcia começa a atender às 8 horas. (imperfectivo, não acabado, habitual).

1.197. Era só ventar um pouco mais frio, Gustavo começava a espirrar. (imperfectivo, não acabado, habitual).

1.198. Embora Jorge começasse a gritar quando me via, dizia à mãe que não tinha medo de mim. (imperfectivo, não acabado, habitual).

No futuro do presente, do pretérito e do subjuntivo, nas formas de sentido futuro do presente e pretérito imperfeito do indicativo (raramente) e do subjuntivo (mais frequentemente) e nos pretéritos perfeito e mais-que-perfeito do indicativo; teremos aspecto inceptivo para a situação narrada, expressa pelo infinitivo, se na frase houver um elemento adverbial que precise o momento de início da situação. Além disso, nos pretéritos perfeito e mais-que-perfeito, temos também o começado para a situação narrada. Poder-se-ia supor que, nas formas de futuro, tivéssemos aspecto não começado para a situação narrada, mas aqui o não começo da situação é apenas deduzido logicamente e não marcado gramaticalmente, portanto não podemos dizer que este aspecto esteja aí expresso (exemplos 1.199 a 1.204). Se não houver o elemento adverbial referido, não teremos aspecto inceptivo para a situação narrada, pois a informação será apenas de que a situação começou ou começará, sem apresentá-la em seu momento de início (exemplos 1.205 a 1.207). Nas formas de futuro, não há aspecto para a situação referencial expressa por "começar ou 
principiar + a + infinitivo" (exemplos 1.199, 1.200, 1.202 a 1.206), enquanto que nos pretéritos perfeito e mais-que-perfeito temos o perfectivo, o acabado e o pontual (exemplos 1.201 e 1.207).

1.199. Sérgio começará a preparar o churrasco quando você chegar. (S.N.: inceptivo).

1.200. Se você permitisse eu começaria a vacinar o gado logo às cinco horas. (S.N.: inceptivo).

1.201. Comecei a pintar estas cadeiras às nove da manhã e não acabei até agora.

a - S.R.: começar a pintar - perfectivo, acabado, pontual.

b - S.N.: pintar - inceptivo, começado.

1.202. Se eu começar a copiar isto agora, te entrego o caderno à tarde. (S.N.: inceptivo).

1.203. É preciso que ele comece a cantar no momento em que a luz incidir sobre ele. (S.N.: inceptivo).

1.204. Se os convidados começassem a chegar às vinte e duas horas, não haveria problema. (S.N.: inceptivo).

1.205. Quando você começa a elaborar seu projeto? (S.N. e S.R.: não aspecto).

1.206. Tenho certeza que Romão começará a imaginar coisas, quando ficar sabendo disso. (S.N. e S.R.: não aspecto).

1.207. Sílvio começara a justificar sua falta, quando percebeu que o chefe não aceitaria nenhuma explicação.

a - S.R.: começar a justificar - perfectivo, acabado, pontual.

b - S.N.: justificar - começado.

\subsection{2 - A PERÍFRASE DE PASSAR}

A perífrase PASSAR + A + INFINITIVO tem, basicamente, as mesmas possibilidades de expressão aspectual que a perífrase "começar + a + infinitivo", diferindo desta principalmente por trazer a implicação de que havia uma situação em realização e houve, está havendo ou haverá uma mudança de situação.

O presente e pretérito imperfeito do indicativo e do subjuntivo têm a possibilidade de expressar o inceptivo, como se pode observar no exemplo (1.208).

1.208. Itamar passava a respirar melhor quando cheguei ao hospital. (imperfectivo, inceptivo, não acabado). 
Embora uma frase como (1.208) seja possível, o falante prefere usar "começar" no lugar de "passar". Na verdade, no presente e pretérito imperfeito do indicativo e do subjuntivo, normalmente temos, com esta perífrase, frases de valor habitual (exemplos 1209 a 1211), ou com valor futuro e sem atualização de aspectos (exemplos 1.212 e 1.213).

1.209. Quando chega o inverno, as pessoas passam a beber mais vinho. (imperfectivo, não acabado, habitual).

1.210. Quando João percebia que eu estava cansada, passava a dançar mais lentamente. (imperfectivo, não acabado, habitual).

1.211. Embora Sérgio sempre passe a trabalhar para a equipe vencedora, não é um mau sujeito. (imperfectivo, inceptivo, habitual).

1.212. De amanhã em diante, passo a caminhar durante uma hora em vez de meia.

1.213. Se Marta passasse a cantar num tom mais baixo, agradaria mais.

Nos pretéritos perfeito e mais-que-perfeito do indicativo, temos os aspectos perfectivo e acabado para a situação referencial de "passar + a + infinitivo" e o aspecto começado para a situação narrada indicada pelo infinitivo (exemplos 1.214 e 1.215). Se na frase houver um elemento adverbial, que indique o momento em que se passou da realização de uma situação para outra, temos também o aspecto inceptivo para a situação narrada (exemplo 1.216), mas isto é pouco comum.

1.214. Desde aquele evento o diretor passou a me respeitar mais.

a - S.R.: passar a respeitar - perfectivo, acabado.

b - S.N.: respeitar - começado.

1.215. Depois do assalto, vovô passara a guardar o dinheiro no banco. a - S.R.: passar a guardar - perfectivo, acabado.

b - S.N.: guardar - começado.

1.216. Às dez horas ele passou a delirar, doutor!

a - S.R.: passar a delirar - perfectivo, acabado.

b - S.N.: delirar - inceptivo, começado.

Nas frases em que a perífrase está numa forma de valor futuro, normalmente não há atualização de aspecto (exemplos 1.217 e 1.218). Se na frase houver um elemento adverbial que indique o momento em que se dará a mudança de situação 
(o que é pouco comum), teremos aspecto inceptivo para a situação narrada expressa pelo infinitivo (exemplo 1.219).

1.217. Tenho certeza de que, depois de ler esse livro, você passará a entender melhor a vida.

1.218. Se você passar a chegar mais cedo em casa, deixará sua mãe mais tranquila.

1.219. Ao meio-dia, o presidente baixará essa alavanca e, nesse exato momento, o rio passará a correr pelo desvio do leito que fizemos.

Também quando combinada à perífrase "estar + gerúndio", a perífrase "passar $+\mathrm{a}+$ infinitivo" expressa aspecto inceptivo. Exemplos:

1.220. Mardem não estará passando a vender mais barato para nos prejudicar? (S.N.: inceptivo).

1.221. O professor está passando a expor com mais clareza. (S.N.: inceptivo).

1.222. Embora ele esteja passando a me respeitar mais, não acredito que ele mude muito. (S.N.: inceptivo).

\subsection{3 - OUTRAS PERÍFRASES INCEPTIVAS}

Neste item, falaremos de um grupo de perífrases que são colocadas no grupo das inceptivas, porque referem que algo começou a ser feito, mas que aspectualmente não são propriamente inceptivas, pelo menos no uso que delas fazem os falantes. Estas perífrases ${ }^{9}$ estão listadas em (1.223) abaixo:

\footnotetext{
${ }^{9}$ Várias destas perífrases são apresentadas por Castilho (1967, p.64-67, 110), como marcando o aspecto "Imperfectivo Inceptivo Propriamente Dito". A quase totalidade dos exemplos por ele apresentados tem o verbo no pretérito perfeito do indicativo, em que ele diz haver este aspecto. Como se verá, nossa análise difere da de Castilho.
} 


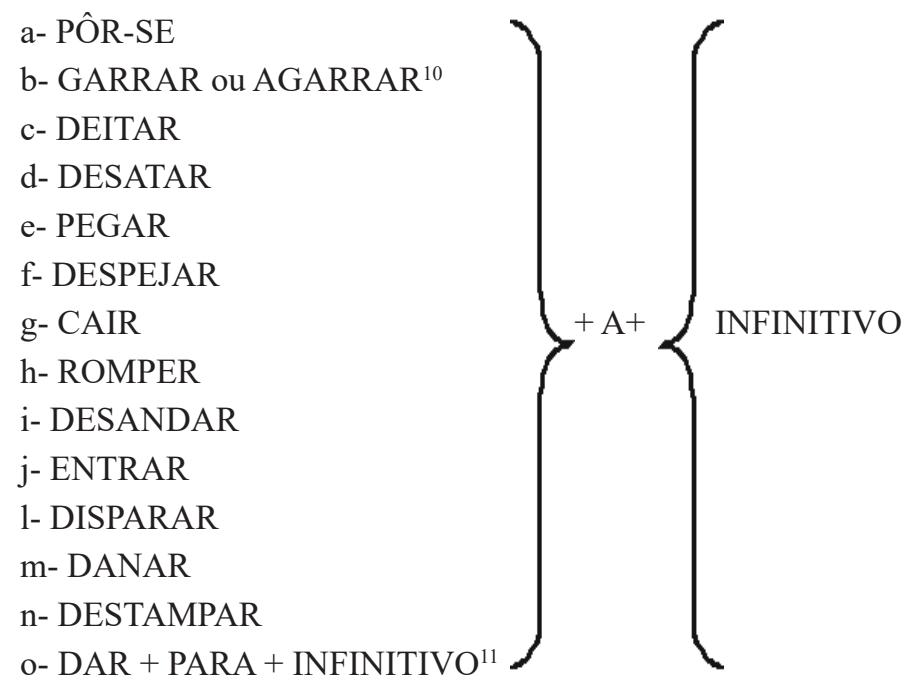

Teoricamente estas perífrases deveriam marcar o aspecto inceptivo nos mesmos casos em que a perífrase "começar + a + infinitivo", mas os falantes não as usam marcando este aspecto. Mesmo se ocorrer (no presente e pretérito imperfeito do indicativo e do subjuntivo), será pouco frequente e natural, como se pode observar nas frases (1.224) e (1.225).

1.224. Quando eu cheguei de manhã os rapazes já se punham a caminhar. (imperfectivo, inceptivo, não acabado).

1.225. Agora os concorrentes entram a procurar os objetos pedidos. (imperfectivo, inceptivo, não acabado).

A frase (1.225) tem de estar colocada num contexto de descrição simultânea para ter este valor, caso contrário, tende a ser interpretada com sentido futuro e aspecto não atualizado.

Nem mesmo em combinação com a perífrase "estar + gerúndio", estas perífrases marcam aspecto inceptivo de maneira frequente ou pelo menos natural. Veja exemplos (1.226) e (1.227).

\footnotetext{
${ }^{10}$ Muitas dessas perífrases são de uso popular apenas. Aulete (1974), Fernandes (1965) e Ferreira (1975) registram os verbos "garrar" e "agarrar", mas não registram este seu uso. (AULETE, F. J. C. Dicionário contemporâneo da língua portuguesa. 3. ed. rev. atual. e aum. Rio de Janeiro: Delta, 1974.).

${ }^{11}$ Aqui poderíamos acrescentar ainda duas perífrases com o auxiliar "dar". Não as colocamos porque têm um uso literário bastante restrito. São elas: DAR-SE + A + INFINITIVO e DAR + EM + INFINITIVO. A perífrase "dar + para + infinitivo" pode também ter o significado de que alguém tem aptidão para fazer algo. Neste caso não temos propriamente uma perífrase mas um sentido particular do verbo dar.
} 
1.226. (?) Cecília está garrando a gritar de medo. (imperfectivo, inceptivo, não acabado).

1.227. (?) Quando você menos esperar, estarei disparando a ganhar dinheiro. (imperfectivo, inceptivo, não acabado).

Diante de frases como (1.224) a (1.227), falantes consultados as aceitam, mas sempre com a ressalva de que são um pouco estranhas, ou de que nunca ouviram ninguém se expressar desta forma.

No presente e pretérito imperfeito do indicativo e do subjuntivo, o que temos, normalmente, é o habitual para a situação referencial expressa pelo todo da perífrase, quase sempre com o auxílio de elementos adverbiais (adjuntos ou orações). Veja exemplos (1.228) a (1.234) abaixo. O aspecto aqui se deve à flexão temporal e outros fatores.

1.228. Joãozinho ficou com tanto medo de injeção que se põe a gritar quando me vê. (imperfectivo, não acabado, habitual).

1.229. Melissa garrava a fazer caretas, quando alguém ralhava com ela. (imperfectivo, não acabado, habitual).

1.230. Embora Dona Zica deite a falar da vida de todos quando está com raiva, não é má pessoa. (imperfectivo, não acabado, habitual).

1.231. Embora Júlia destampasse a engordar quando começava a comer muito doce, não conseguia se controlar. (imperfectivo, não acabado, habitual).

1.232. De vez em quando, meu irmão dá para esperar-me na porta do colégio. (imperfectivo, não acabado, habitual).

1.233. Quando ficava nervosa, Diná desatava a quebrar coisas. (imperfectivo, não acabado, habitual).

1.234. Embora Carlota rompa a maldizer quando se enfurece, na verdade não deseja o mal a ninguém. (imperfectivo, não acabado, habitual).

Às vezes o habitual é limítrofe com o indeterminado (exemplo 1.235), e é difícil a decisão entre um e outro.

1.235. A pessoa que está com falta de vitaminas dá para adoecer com frequência.

A maioria destas perífrases aparece mais frequentemente no pretérito perfeito do indicativo Algumas, em verdade, quase que só são usadas neste tempo e é interessante observar que todas elas formam frases mais naturais quando nele 
empregadas. No pretérito perfeito e também no pretérito mais-que-perfeito do indicativo, temos os aspectos perfectivo, acabado e pontual para a situação referencial, indicada pelo todo da perífrase, e o aspecto começado para a situação narrada, indicada pelo infinitivo. Exemplos:

1.236. Mais tarde, Márcia entendeu a piada e pegou a rir.

a - S.R.: pegar a rir - perfectivo, acabado, pontual.

b - S.N.: rir - começado.

1.237. Diante da pergunta do professor Benedito, Paulo despejara a recitar o ponto que sabia de cor, mas do qual não entendera nada. a - S.R.: despejar a recitar - perfectivo, acabado, pontual. b - S.N.: recitar - começado.

1.238. Elza, vencida pelo cansaço, caiu logo a dormir. a - S.R.: cair a dormir - perfectivo, acabado, pontual. b - S.N.: dormir - começado.

1.239. Mamãe chamou o médico, porque Suzaninha desandara a comer terra.

a - S.R.: desandar a comer - perfectivo, acabado, pontual. b - S.N.: comer - começado.

Se na frase houver um elemento adverbial que precise o momento de início da situação, teremos também o aspecto inceptivo para a situação narrada. Exemplos (1.240) e (1.241).

1.240. Ao meio dia, destampou a cair pedras do céu. a - S.R.: destampar a cair - perfectivo, acabado, pontual. b - S.N.: cair - inceptivo, começado.

1.241. Ao me ver, o cachorro danara a latir, acordando todo mundo. a - S.R.: danar a latir - perfectivo, acabado, pontual. b - S.N.: latir - inceptivo, começado.

No futuro do presente, do pretérito e do subjuntivo e nas formas de valor futuro dos demais tempos (principalmente do presente e pretérito imperfeito do indicativo e do subjuntivo) não há atualização de aspecto. Exemplos:

1.242. Não vou contar isso a Tereza, porque tenho certeza que ela porse-á a gritar como uma louca. 
1.243. Se eu não a tivesse ajudado, ela desandaria a dizer que sou um malvado.

1.244. Se Rogério destampar a mexer com todo mundo, eu não fico com vocês na praia.

1.245. É possível que Nicomedes dane a procurar um selo destes, só para satisfazer o filho.

Se na frase houver um elemento adverbial que precise o momento de início da situação teremos o aspecto inceptivo para a situação narrada indicada pelo infinitivo, com o verbo nas formas futuras acima indicadas. Exemplo:

1.246. Às vinte e duas horas os fogos de artifício romperão a explodir no céu. (S.N.: explodir - inceptivo).

Às vezes, temos gerúndio no lugar de infinitivo. Castilho (1967, p.65) apresenta alguns exemplos, dois dos quais transcrevemos abaixo.

1.247. "Contemplando essa gente do segundo andar, me ponho imaginando a classe a que pertence." - (M. de Andrade)

1.248. "Crianças danadas para incomodar são as de entre um ano e cinco, que se chateiam logo e pegam choramingando: Mamãe, quero ir para casa $[\ldots] "$ " - (R. de Queirós)

Todas estas perífrases atribuem à situação expressa pelo infinitivo um valor intensivo que termina por levar, frequentemente, a um valor iterativo ${ }^{12}$, principalmente se o verbo expressa um evento (exemplo 1.249), mas também com processos (exemplos 1.250 e 1.251). Castilho (1967, p.19 e 66-7) também aponta para esse valor iterativo, dizendo que, com DAR + PARA + INFINITIVO, ele sempre aparece (exemplo 1.250). Said Ali (1964, p.163) já observa que, "para significar que algum dos atos é duradouro ou se repete (negrito nosso) com frequência, empregamos em lugar do imperfeito usado na linguagem antiga, as formas perifrásticas pôr-se a fazer alguma coisa ou começar a fazer alguma coisa". Apesar desse valor iterativo para a situação narrada, não podemos falar em aspecto iterativo, pois a repetição da situação é logicamente deduzida, mas não gramaticalmente marcada.

\subsection{Virgílio pôs-se a pular como um cabrito.}

${ }^{12}$ Esse valor iterativo aparece também com as perífrases inceptivas citadas anteriormente. 
1.250. De uns tempos para cá ele deu para ler romances policiais.

1.251. Depois daquela notícia Hugo destampou a comprar terrenos.

\subsection{5 - As PERÍFRASES DE SER}

\subsection{1 - SER + PARTICÍPIO}

A perífrase SER + PARTICÍPIO de verbo transitivo, que aceita a voz passiva, não marca aspecto, mas sim a voz passiva. O aspecto vai ser o expresso pela flexão verbal e outros elementos. Exemplos (entre parênteses indicamos a que se deve o aspecto).

1.252. Os filhos são amados pelos pais. (imperfectivo, não acabado, indeterminado) (presente do indicativo).

1.253. Os quartos são limpos todos os dias. (imperfectivo, não acabado, habitual) (presente do indicativo e adjunto adverbial "todos os dias").

1.254. Quando os encontramos, a criança era conduzida pelo pai. (imperfectivo, cursivo, não acabado, durativo) (pretérito imperfeito do indicativo e oração adverbial temporal que funciona como presentificador).

1.255. Os troncos foram serrados com todo cuidado. (perfectivo, acabado).

1256. A música será cantada por um coro de crianças. (não aspecto) (futuro do presente).

1.257. Embora as roseiras sejam podadas em julho, só florescem em setembro. (imperfectivo, não acabado, habitual) (presente do subjuntivo e adjunto adverbial "em julho").

Embora haja possibilidade de expressão do cursivo no presente e pretérito imperfeito do indicativo e do subjuntivo, o falante sempre prefere a combinação com "estar + gerúndio" para deixar patente a presença deste aspecto. Exemplo:

1.258. Os galhos estão sendo cortados para facilitar o trabalho de transporte. (imperfectivo, cursivo, não acabado, durativo). 


\subsection{2 - SER + PARTICÍPIO VARIÁVEL}

A perífrase SER + PARTICÍPIO variável de verbo intransitivo marca o aspecto acabado para a situação narrada, que é a situação de cuja realização resulta o estado ( situação referencial) expresso pela forma. Este terá aspecto imperfectivo, cursivo, não acabado e durativo.

Esta construção normalmente só aparece no presente e no pretérito imperfeito do indicativo, sendo pouco usada atualmente. Seguro Câmara Jr., hoje ela só aparece esporadicamente na língua literária.

Bechara (1977, p.111) apresenta esta construção como exprimindo que a ação verbal está concluída. Câmara Júnior (1974a, p.86) diz que ela marca aspecto permansivo.

Vejamos alguns exemplos:

1.259. Era chegada a ocasião da fuga.

1.260. São passados três meses.

1.261. "Meu Deus, meu Deus, pois a isto somos chegados."13

\subsection{3 - SER + DE + INFINITIVO}

A perífrase SER + DE + INFINITIVO marca o aspecto habitual para a situação narrada indicada pelo infinitivo e o aspecto indeterminado, para a situação referencial indicada pelo todo da perífrase, com todas as flexões verbais. Outros aspectos presentes na frase vão depender destas flexões ou de outros fatores. O verbo "ser" mantém seu status de verbo de estado, o que nos dá os fatos de expressão dos aspectos já comentados, quando falamos das flexões verbais, como, por exemplo, a expressão do acabado nos pretéritos perfeito e mais-que-perfeito do indicativo.

As frases construídas com esta perífrase têm sempre a função de caracterizar seres e coisas (cf. item 4.2.5), em que "de + infinitivo" tem valor adjetivo, indicando a característica do sujeito criada pelo hábito de realizar a situação expressa pelo infinitivo.

O que acabamos de dizer pode ser observado nos exemplos (1262) a (1270).

${ }^{13}$ Os exemplos (1259) e (1260) são de Bechara (1977, p.111). Exemplo (1261) apud Câmara Júnior (1974a, p.86). Said Ali (1971, p.160, § 816) apresenta vários exemplos com a construção em estudo. 
1.262. Eu não sou de levar desaforos para casa.

a - S.R. - imperfectivo, não acabado, indeterminado.

b - S.N. - habitual.

1.263. Abadio era de partir sem se despedir de ninguém.

a - S.R. - imperfectivo, não acabado, indeterminado.

b - S.N. - habitual.

1.264. Mário foi de amar uma hoje outra amanhã, até que encontrou o verdadeiro amor.

a - S.R. - perfectivo, acabado, indeterminado.

b - S.N. - habitual.

1.265. Ildefonso nunca fora de desrespeitar ninguém, por isso todos estranharam sua atitude.

a - S.R. - perfectivo, acabado, indeterminado.

b - S.N. - habitual.

1.266. Este menino, quando for moço, será de chegar tarde em casa.

a - S.R. - indeterminado.

b - S.N. - habitual.

1.267. Hilda seria de chegar atrasada aos lugares, se o marido não estivesse sempre a apressá-la.

a - S.R. - imperfectivo, não acabado, indeterminado.

b - S.N. - habitual.

1.268. Embora Josafá seja de ajudar todo mundo, não quis ajudar-me.

a - S.R. - imperfectivo, não acabado, indeterminado.

b - S.N. - habitual.

1.269. Embora César fosse de observar tudo, não percebeu a modificação que fiz na sala.

a - S.R. - imperfectivo, não acabado, indeterminado.

b - S.N. - habitual.

1.270. Sendo de dizer a verdade, Guilherme não aceitava a ideia de ter que mentir daquela vez.

a - S.R. - imperfectivo, não acabado, indeterminado.

b - S.N. - habitual.

\subsection{6 - DifERENÇAS ENTRE AS PERÍfRASES QUE EXPRESSAM O MESMO ASPECTO}

Como se pôde observar, é frequente termos mais de uma perífrase para expressão do mesmo aspecto. Pode-se notar, entretanto, que normalmente há uma diferença entre elas. Essa diferença se deve, quase sempre, à expressão de uma 
noção semântica qualquer ou de uma noção de tempo, ou é apenas uma diferença de uso em registros ou dialetos distintos.

Neste item, não fazemos uma análise minuciosa das diferenças existentes entre as perífrases que expressam o mesmo aspecto, apenas damos alguns exemplos a título de esclarecimento.

A diferença entre "estar + gerúndio" e "vir + gerúndio" é temporal: a primeira se refere apenas ao momento em que se fala ou de que se fala; a segunda indica que a situação se desenvolve até o momento em que se fala ou de que se fala, a partir de um momento anterior a eles. Considerando os casos em que "ir + gerúndio" também marca os aspectos imperfectivo, cursivo, não acabado e durativo, temos um sistema completo na língua que representamos no esquema de (1.271).

1.271.

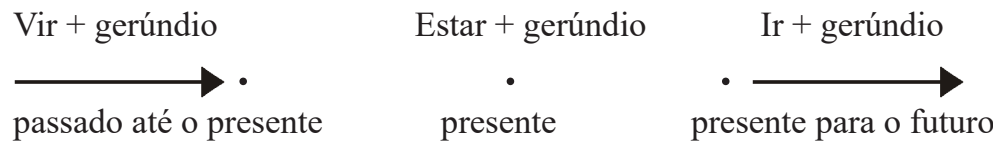

"Ter (no presente do indicativo) + particípio" e "Andar + gerúndio", ambas marcadoras de iterativo, também se distinguem pelo tempo, como demonstrado pelo esquema (1272).

1.272 .

Ter (presente do indicativo) + particípio

Andar + gerúndio

$\longrightarrow$ passado até o presente

presente

"Andar + gerúndio", quando marca cursivo e durativo em vez de iterativo, é diferente de "estar + gerúndio", porque se refere a um período de tempo maior que o referido pela segunda perífrase que só evoca um momento.

As perífrases "estar + por + infinitivo", "estar + gerúndio" e "estar + particípio" se distinguem, como já dissemos, por atribuir à situação expressa pelo verbo principal, respectivamente os aspectos não começado, começado ou não acabado e acabado. Constituem, assim, um sistema completo em relação às fases de realização.

Já especificamos, em 8.3.1, a diferença entre as perífrases de aspecto não começado com o auxiliar "estar". "Ficar + por + infinitivo" se distingue das três perífrases com "estar" por indicar que o estado de "por + infinitivo" permanece além de um limite previsto para o seu fim. 
As perífrases "ter + particípio" e "haver + particípio" apresentam uma diferença de registro já que a segunda, além de pouco usada, aparece quase que exclusivamente na linguagem culta e literária.

"Estar + para + infinitivo", "ir + infinitivo" e "ir (pretérito imperfeito do indicativo) + gerúndio", quando marcando iminência de ação, diferem, por expressar, nesta ordem, um grau crescente de iminência.

As perífrases que marcam o aspecto habitual diferem da seguinte maneira: "viver + gerúndio" e "viver + a + infinitivo" (a segunda sendo pouco usada) marcam o habitual, para processos e eventos, enquanto "viver + particípio" o marca para os estados. "Ser + de + infinitivo" marca o habitual sempre com a função de caracterizar seres e coisas. "Costumar + infinitivo" marca o habitual para processos e eventos, e difere das perífrases de viver pela frequência de realização da situação que é maior com a perífrase de viver. "Usar + infinitivo" tem o mesmo valor de "costumar + infinitivo", tendo aplicação mais restrita, pois normalmente, é usada apenas com sujeito caracterizado como humano.

Além das diferenças de significado já especificadas em 8.14, as perífrases inceptivas, normalmente, se distinguem por serem variantes regionais ou de registros. Assim, por exemplo, "entrar + a + infinitivo" é mais usada em Portugal que no Brasil. "Pôr-se + a + infinitivo" normalmente é usada em um padrão mais culto de linguagem, enquanto "disparar, danar e destampar ${ }^{14}+\mathrm{a}+$ infinitivo" têm uso mais popular e familiar. Há também diferenças de significado, pois "romper $+\mathrm{a}+$ infinitivo", por exemplo, expressa um início mais momentâneo e com uma certa concentração de energia do sujeito, que não existe nas demais perífrases. A determinação das diferenças de significado entre as perífrases de (1.223) exige uma análise sêmica que não cabe fazer aqui, mas fica como sugestão para estudos posteriores.

\subsection{7 - CONSIDERAÇÕES FINAIS}

É interessante observar que o único aspecto que não é marcado por perífrase é o pontual. Considerando que temos várias perífrases que marcam o aspecto durativo, confirma-se aqui o que afirmamos em 3.1: que a Língua Portuguesa tende a apresentar as situações, mais como durativas do que pontuais.

Há de se anotar também que nenhuma perífrase marcadora de aspecto imperfectivo, ou de tendência imperfectiva, leva os pretéritos perfeito e mais-que-perfeito do indicativo a deixar de marcar o aspecto perfectivo. Dessa forma, todas as perífrases, nestes dois tempos, têm aspecto perfectivo.

\footnotetext{
${ }^{14} \mathrm{O}$ dicionário Caldas Aulete registra esse uso do verbo destampar como familiar.
} 
É interessante observar que, normalmente, quando a situação narrada tem aspecto não acabado, a perífrase é com "gerúndio" ou "a + infinitivo" e, quando ela é acabada, a perífrase é de "particípio". Isto está ligado ao fato, já referido, de que o gerúndio apresentaria a situação como não acabada e o particípio, como acabada.

Uma outra possibilidade de estudo que existe é verificar os aspectos expressos por combinações de perífrases. Aqui referimos alguns casos, principalmente de combinação da perífrase "estar + gerúndio" com perífrases inceptivas e terminativas (ver itens 8.10 a 8.14), mas não fizemos um estudo mais detalhado das possibilidades aspectuais de semelhantes combinações. Fica aqui a sugestão para futuros trabalhos.

Tendo falado sobre a expressão do aspecto pela flexão temporal e pelas perífrases que, como dissemos, mereceria particular atenção, passamos a falar dos demais recursos. Nós o faremos da forma mais sintética possível, apresentando o resultado das observações feitas, mas sem nenhuma pretensão de apresentar um estudo mais detalhado da questão. Nosso objetivo é, tão somente, não deixar de registrar informações úteis e necessárias à compreensão do problema da expressão do aspecto. 